\title{
Review Article \\ Involvement of DNA Damage Response Pathways in Hepatocellular Carcinoma
}

\author{
Sheau-Fang Yang, ${ }^{1,2}$ Chien-Wei Chang, ${ }^{3,4}$ Ren-Jie Wei, ${ }^{3,5,6}$ Yow-Ling Shiue, ${ }^{6}$ \\ Shen-Nien Wang, ${ }^{7,8}$ and Yao-Tsung Yeh ${ }^{3}$ \\ ${ }^{1}$ Department of Pathology, Kaohsiung Municipal Ta-Tung Hospital, Kaohsiung City 801, Taiwan \\ ${ }^{2}$ Department of Pathology, Faculty of Medicine, College of Medicine, Kaohsiung Medical University, Kaohsiung City 807, Taiwan \\ ${ }^{3}$ Department of Medical Laboratory Sciences and Biotechnology, Fooyin University, Kaohsiung City 831, Taiwan \\ ${ }^{4}$ Cancer Center and Division of General \& Gastroenterological Surgery, Department of Surgery, Kaohsiung Medical University Hospital, \\ Kaohsiung City, Taiwan \\ ${ }^{5}$ Department of Pathology, Kaohsiung Armed Forces General Hospital, Kaohsiung City 802, Taiwan \\ ${ }^{6}$ Department of Biological Sciences, National Sun Yat-sen University, Kaohsiung City 804, Taiwan \\ ${ }^{7}$ Department of Surgery, Faculty of Medicine, College of Medicine, Kaohsiung Medical University, Kaohsiung City 807, Taiwan \\ ${ }^{8}$ Division of Hepato-Pancreatico-Biliary Surgery, Kaohsiung Medical University Hospital, Kaohsiung City 807, Taiwan
}

Correspondence should be addressed to Shen-Nien Wang; snwang@cc.kmu.edu.tw and

Yao-Tsung Yeh; glycosamine@yahoo.com.tw

Received 8 November 2013; Revised 23 January 2014; Accepted 25 March 2014; Published 28 April 2014

Academic Editor: Wei Mike Liu

Copyright (C) 2014 Sheau-Fang Yang et al. This is an open access article distributed under the Creative Commons Attribution License, which permits unrestricted use, distribution, and reproduction in any medium, provided the original work is properly cited.

Hepatocellular carcinoma (HCC) has been known as one of the most lethal human malignancies, due to the difficulty of early detection, chemoresistance, and radioresistance, and is characterized by active angiogenesis and metastasis, which account for rapid recurrence and poor survival. Its development has been closely associated with multiple risk factors, including hepatitis B and C virus infection, alcohol consumption, obesity, and diet contamination. Genetic alterations and genomic instability, probably resulted from unrepaired DNA lesions, are increasingly recognized as a common feature of human HCC. Dysregulation of DNA damage repair and signaling to cell cycle checkpoints, known as the DNA damage response (DDR), is associated with a predisposition to cancer and affects responses to DNA-damaging anticancer therapy. It has been demonstrated that various HCC-associated risk factors are able to promote DNA damages, formation of DNA adducts, and chromosomal aberrations. Hence, alterations in the DDR pathways may accumulate these lesions to trigger hepatocarcinogenesis and also to facilitate advanced HCC progression. This review collects some of the most known information about the link between HCC-associated risk factors and DDR pathways in HCC. Hopefully, the review will remind the researchers and clinicians of further characterizing and validating the roles of these DDR pathways in HCC.

\section{The Common Causes of Genetic Alterations and Genomic Instability in HCC}

Liver cancer is the sixth most common cancer overall but the third most frequent cause of cancer death $[1,2]$. Among primary liver cancers, hepatocellular carcinoma (HCC), the major histological subtype, is associated with multiple risk factors, including hepatitis $\mathrm{B}$ and $\mathrm{C}$ virus (HBV and $\mathrm{HCV}$ ) infection, alcohol consumption, obesity, and diet contamination (Figure 1). HCC frequently arises in the context of chronic injury and inflammation that promote DNA damage and chromosomal aberrations [3], which trigger a prompt set of signaling events known as the DNA damage response (DDR) pathways which coordinate DNA repair, cell cycle arrest, and ultimately cell death or senescence [4-6]. There are several types of DNA damage and corresponding repair 
HCC-associated risk factors

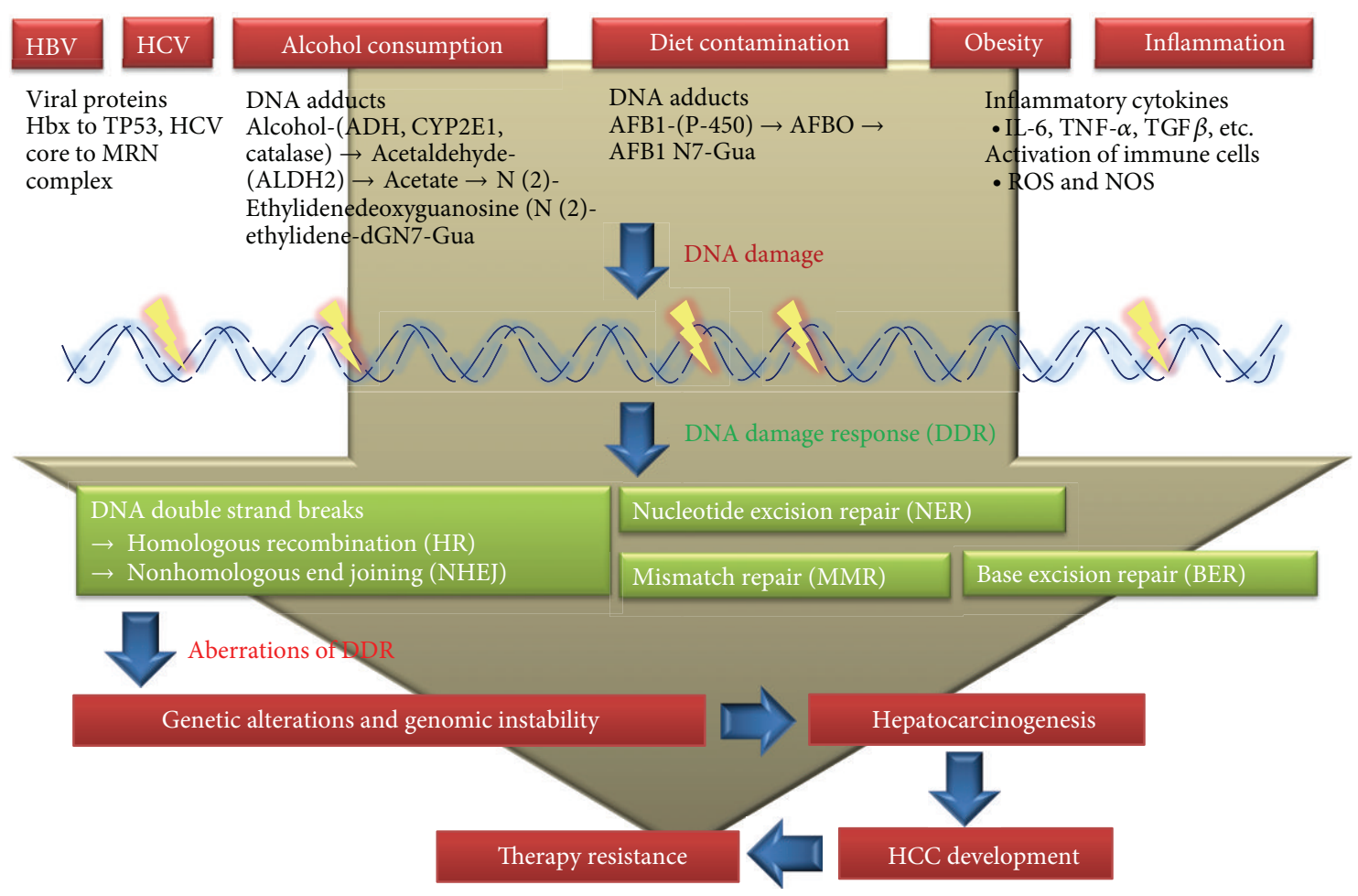

(a)

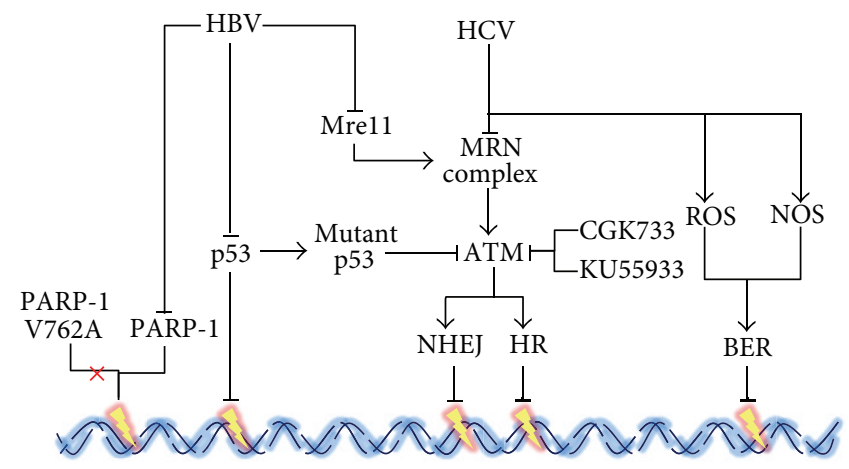

(b)

Figure 1: (a) A diagram of the potential involvement of DDR pathway in HCC. (b) Short summary of the link between HBV and HCV infections and DDR pathways in HCC.

mechanisms that have been implicated in HCC such as stalled DNA replication fork by homologous recombination (HR) [7], base mismatches by mismatch repair (MMR) [8], and the most serious form of DNA damage, double-strand break (DSB) [9], by nonhomologous end joining (NHEJ) [10, 11] (Figure 1). Aberrations of DDR may ravage genomic integrity, trigger hepatocarcinogenesis, and facilitate advanced HCC development. It is increasingly recognized that both genetic alteration and genomic instability are common features of human HCC. Hence, better understanding of the roles of DDR pathways may help us to develop the strategies for treatment or prevention of HCC. It will be worthy to remind people of the importance of DDR pathways in HCC.

Genomic instability including telomere erosion [12-14], chromosome segregation defects $[15,16]$, and alterations in the DDR pathways $[17,18]$ has been regarded as a common feature of human HCC. Various genetic alterations accumulate during hepatocarcinogenesis that change the signal transduction network [19]. Although different types of liver carcinogenesis models have been described [19-22], the direct link of genetic and epigenetic changes to this cancer remains undetermined. A failure to repair these genetic or 
genomic alterations probably resulted from DNA damages, caused by many risk factors, may lead to hepatocarcinogenesis and continuously contribute to further HCC progression. In addition to its direct impacts on genomic integrity, DNA damage can also increase viral DNA integration into the host genome [23]. Integration of HBV DNA and resulting induction of genomic instability is one of the proposed mechanisms suggested for HBV-related liver carcinogenesis [24]. In addition, HBV DNA integration can also occur in human satellite DNA sequences [25]; genomic repetitive sequences are suspected to be hotspots for HBV DNA integration [26].

Frequent mutations of coding nucleotide repeats are thought to contribute significantly to carcinogenesis associated with microsatellite instability (MSI), one kind of genomic instability. Microsatellite alterations have been widely and frequently reported, mainly when cirrhosis is associated with HBV infection [27-31]. However, the frequency of MSI in HCC tumors exhibits large variations. More than 10\% (10-43\%) of HCCs in European, American, Japanese, and black Southern African patients have been shown to exhibit MSI at one or more microsatellite markers [28-38], whereas this phenotype has rarely been observed in other European, American, Japanese, Taiwanese, Korean, and Chinese series of HCC tumors [39-47]. Several human cancers have been under extensive loss of heterozygosity (LOH), another kind of genomic instability, including breast cancer, ovarian cancer, renal cell carcinoma, HCC, lung cancer, and colorectal cancer; a number of deleted chromosomal regions that are important in those cancers have been identified [4852].

Since with genetic alterations, genomic instability, and alterations of DDR pathways have been recognized as a common characteristic of HCC, we will shortly review their relationships with multiple risk factors, including hepatitis $\mathrm{B}$ and $\mathrm{C}$ virus infection, alcohol consumption, and diet contamination as follows.

\subsection{Common Chemical Carcinogens in HCC Development.} The aflatoxin-liver cancer risk relationship is one of the most documented examples of a disseminated environmental chemical carcinogen [53]. Aflatoxin B1 (AFB1), a wellestablished animal hepatocarcinogen, is a suspected HCC risk factor in hyperendemic areas like Sub-Saharan Africa, Southeast Asia, and Southern China, where dietary staples are highly contaminated [17]. Prospective epidemiological studies have shown a more than multiplicative interaction of $\mathrm{HBV}$ or HCV and aflatoxins in terms of HCC risk. Studies of the metabolism of AFB1 revealed that the compound is activated to its electrophilic DNA-binding form through an epoxidation pathway. Furthermore, activation and DNA binding produces identical DNA adduct profiles, with the N7 position of guanine representing the only site of adduct formation [18]. In regions where exposure to AFB1 and chronic exposure to $\mathrm{HBV}$ are frequently concomitant, there is a high incidence of HCC that often harbors TP53 mutations [54]. It is possible that aflatoxin-induced DNA adducts are fixed as mutations due to the HBV-related increase in cell proliferation and hyperplasia, thus promoting the clonal expansion of mutant cells. Mutations of TP53 such as the transversion in codon 249 (guanine $(\mathrm{G})$ to thymine $(\mathrm{T})$ ), which causes an arginine $(\mathrm{R})$ to serine (S) substitution, are present in $50 \%$ of HCCs $[55,56]$ and have been related to consumption of AFB1-contaminated food $[57,58]$. Studies from Qidong and Guanxi, China, and South Africa revealed that the mutation occurs at the codon 249 hotspot in exon 7 of the TP53 gene in HCC patients [57, 59-62]. The target organ for metabolism of AFB1 is the liver. Following ingestion with AFB1-contaminated food, AFB1 may be metabolized by cytochrome $\mathrm{P} 450$ enzymes to reactive genotoxic intermediates (aflatoxin B1-8,9-oxide, AFBO) or hydroxylated (to AFQ1 and AFM1) and demethylated (to AFP1) to become less harmful than AFB1. The highly reactive genotoxic compound, AFBO, can bind to liver cell DNA as a result, and DNA adducts are formed, namely, 8,9dihydro-8 (N7guanyl)-9-hydroxy-AFB1 (AFB1 N7-Gua) [6366]. If this is not repaired before DNA replication, the DNA adducts interact with the guanine base of the DNA and cause mutational effects in the TP53 tumor suppressor gene [63, $65,67]$, resulting in hepatocarcinogenesis. Mutated R249STP53 protein expression may lead to inhibition of apoptosis, inhibition of TP53-mediated transcription, and stimulation of liver cell growth in vitro [55].

Malignant transformation of hepatocytes may occur as a consequence of various aetiologies, such as alcohol, in the context of increased cellular turnover induced by chronic liver injury, regeneration, and cirrhosis. Alcohol intake has been definitely recognized as a cause of chronic liver diseases, including HCC [68]. An indirect mechanism includes the development of cirrhosis, which is probably the most common pathway to liver carcinogenesis in developed countries [69]. Chronic alcohol use of greater than $80 \mathrm{~g} /$ day for more than 10 years increases the risk for HCC approximately 5-fold. Nevertheless, alcohol use of less than $80 \mathrm{~g} /$ day is associated with a nonsignificant increased risk for HCC [70]. The risk does not decrease with abstinence because HCC can also occur in a noncirrhotic liver. The mechanisms by which alcohol causes HCC are incompletely understood but may include chromosomal loss, oxidative stress, a decreased retinoic acid level in the liver, altered DNA methylation, and genetic susceptibility [68]. Acetaldehyde, the primary metabolite of ethanol, is suspected to play a major role in alcohol-related carcinogenesis. The binding of DNA and formation of DNA adducts represent one mechanism by which acetaldehyde could trigger the occurrence of replication errors or mutations in oncogenes or tumor suppressor genes [71, 72]. Thus, the development of acetaldehyde-derived DNA adducts may be an important mechanism in the carcinogenicity of alcoholic beverages [73]. Ingested ethanol is mainly oxidized by the enzymes alcohol dehydrogenase (ADH), cytochrome P-450 2E1 (CYP2E1), and catalase to form acetaldehyde, which is subsequently oxidized by aldehyde dehydrogenase 2 (ALDH2) to produce acetate. N (2)-Ethylidenedeoxyguanosine (N (2)-ethylidene$\mathrm{dG})$ is the major adduct formed in this reaction. Although some DNA adducts formation is demonstrated to be an initiation step of carcinogenesis [74, 75], it is still unclear whether these alcohol-related DNA adducts are true factors or initiators of cancer. Future studies are needed to better 
characterize and to validate the roles of these DNA adducts in human study.

1.2. The Link between Inflammation and ROS-Mediated DNA Damage to HCC Development. Activated inflammatory cells release free radicals, such as reactive oxygen species (ROS) and nitric oxide reactive species (NOS), which in turn can cause DNA damage and lead to gene mutations, thus fostering neoplastic transformation. Inflammation and oxidative stress associated with chronic active hepatitis may result in DNA damage and mutations. The chronic inflammation is characterized by the continued expression of cytokines and recruitment of immune cells to the liver. In fact, hepatic oxidative stress is also strongly associated with increased risk for HCC in patients with chronic HBV and HCV infections $[76,77]$. On the other hand, obesity and inflammationassociated metabolic disorders are also able to promote increased secretion of cytokines (known as adipokines) by adipose tissue [78], as well as inflammatory cells, which include resident liver macrophages or Kupffer cells (KCs) [78, 79]. Hypertrophic adipocytes resulted from deposition and accumulation of excess lipids secrete free fatty acids (FFAs), and together with various immune cells which release various proinflammatory cytokines including tumor necrosis factor (TNF), interleukin-6 (IL-6), IL-1 $\beta$, IL-8, IL-10, IL-18, and IL17 , as well as more specialized adipokines, such as leptin and adiponectin [78, 80-85]. Among all of these cytokines, IL6 is both proinflammatory and a useful marker for obesityassociated inflammation. In the liver, IL-6 is mainly secreted by KC and hepatic stellate cells (HSC) and to a lesser extent by stimulated hepatocytes $[86,87]$. Earlier studies have also revealed that both IL- 6 and TNF increase hepatic production of C-reactive protein (CRP), a major acute phase protein, which is a nonspecific but sensitive marker of infection and tissue inflammation that is increased in obesity [88-90].

The balance of cytokines is also critical for regulating the type, extent, function, and outcome of inflammatory cell infiltrates. Profibrotic cytokines (IL-4 and IL-13) are produced by the increased population of NKT cells in chronically infected livers [91, 92]. Emerging data suggest that the inflammatory milieu represents a favorable niche for genetic mutations leading to cancer. A consequence of chronic inflammatory responses initiated by viral infection is the release of free radicals, such as ROS and NOS [93, 94]. The inflammatory response includes the activation of macrophage and neutrophil cells that result in a complex spectrum of chemically reactive species that damage DNA and other biomolecules [95]. Activated macrophages overproduce $\mathrm{NO}$ and superoxide $\left(\mathrm{O}_{2 i}{ }^{-}\right)$that combine rapidly to form peroxynitrite $\left(\mathrm{ONOO}^{-}\right)$. The latter decomposes to reactive intermediates that can cause damage to DNA and other biomolecules. The activated neutrophils, on the other hand, contribute to the myeloperoxidase-mediated generation of hypochlorous acid $(\mathrm{HOCl})$ - a potent oxidizing and halogenating agent [95]. While many of the DNA lesions formed are oxidized forms of DNA bases themselves [96, 97], more bulky DNA lesions can also arise from the endogenous peroxidation of lipids that generate highly reactive aldehyde derivatives that react with DNA [98]. The generation of guanine radical intermediates also leads to the formation of cross-linking reactions with thymine $[98,99]$. Intriguingly, NO could contribute to viral persistence by means of its antiapoptotic effect in hepatocytes and may itself induce viral mutations and promote a selective suppressive effect on Th1 cells [94]. NO can also directly influence liver cell survival by preventing apoptosis through activation of the nuclear factor kappa B (NF- $\kappa$ B) signaling pathway [100]. ROS and other oxidative stress-related intermediates contribute to death, the perpetuation of chronic inflammatory responses, fibrogenesis, with a major focus on hepatic chronic wound healing, and liver fibrogenesis [101]. In addition, ROS are also involved in necrosis and apoptosis of hepatocytes and HSC activation [102, 103]. Together, these oxygen-derived free radical species are able to induce several alterations and structure/function modifications of cancer-related proteins and gene mutations, including those related to cell-cycle control, apoptosis, lipid peroxidation, and DNA repair.

The chronic inflammation affects many cellular pathways, leading to fibrosis and cirrhosis and finally hepatocarcinogenesis. Liver injury induces tissue repair and liver regeneration, which involve deregulated growth and death of hepatocytes. High cell turnover induces several critical alterations for malignant transformation, including structural and/or functional modifications of proteins involved in cell-cycle control, apoptosis, oxidative stress, lipid peroxidation, and DNA repair damage $[104,105]$. Moreover, TNF- $\alpha$-induced $\mathrm{NF}-\kappa \mathrm{B}$ activation plays a key role in hepatocarcinogenesis $[106,107]$.

Several major classes of free radical scavengers, such as catalase, superoxide SOD, and glutathione peroxidase (GSH$\mathrm{P}$ ), were investigated in various types of liver damage, and they afforded effective protection against the oxidative insults to hepatic parenchyma [108]. High levels of ROS, from phagocytic cells, such as KCs, protect the organism from external pathogens; however, lower amounts of ROS mainly from HSC actively participate in the regulation of intracellular signaling $[103,109]$. Platelet-derived growth factor (PDGF) is the most potent mitogen of HSC and is, therefore, likely to be an important mediator during liver fibrogenesis [110]. Interestingly, $\mathrm{NAD}(\mathrm{P}) \mathrm{H}$ is expressed in $\mathrm{HSC}$ and produces ROS, which, in turn, induces the production of PDGF; again, this molecule increases mitosis of HSC [109]. These results strongly suggest that ROS plays an important role in fibrogenesis increasing PDGF throughout.

\section{The Impact of DDR Pathways on HCC Development}

It has been revealed that aberrations of DNA repair proteins such as hOGG1, XRCC1, TP53, Poly(ADP-ribose) polymerase 1 (PARP-1), Mre11-Rad50-Nbs1 (MRN) complex, and ataxia telangiectasia-mutated (ATM) kinase were correlated with HCC [111-117]. Lack of Ku70, a DNA repair protein that takes part in NHEJ pathway, showed high proliferative activity with increased cyclin D1 and loss of TP53 via proteasomal degradation, thus suggesting that defects in NHEJ pathway 
lead to chromosomal instability and facilitate development of HCC [118]. In addition, MRN complex, a DSB sensor [119] and DNA binding protein [120], recruits ataxia ATM to participate in two major DNA repair pathways that are responsible for DSB: HR and NHEJ [121-123]. It has also been reported that mutant TP53 can interact with Mrell and thereby impair the proper function of MRN complex and subsequent activation of ATM [124]. Moreover, inactivation of DNA repair contributes to development of HCC has been revealed $[125,126]$.

Base excision repair (BER) pathway constitutes the primary defense mechanism against lesions generated by DNA damaging agents like viruses [127]. Two DNA repair genes, hOGG1 and XRCC1 that encode DNA glycosylase enzyme [113] and scaffold protein [128] responsible for BER pathway, have been implicated with hepatitis virus-related liver cancer [129-131]. Furthermore, genetic polymorphisms of DNA repair genes reduce DNA repair capacity [132]. For instance, hOGG1, Cys326Cys, and Ser326Cys genotypes' XRCC1 codon 399 variant Arg/Gln allele has been recently shown to be associated with increased HCC risk (Table 1) [111, 112]. Recent study has also reported that Ser326Cys polymorphism in hOGGl gene is associated with HCC carcinogenesis in Eastern Asians [113]. The nucleotide excision repair (NER) process is the most important repair pathway for elimination of DNA damage caused by exogenous agents including UV light, DNA-adducing carcinogens, and some endogenously generated oxidative lesions [133]. NER is a multistep process involving more than 25 polypeptides; it consists in an initial damage recognition step, followed by an incision to either side of the lesion and the removal of the damage-containing oligonucleotide, DNA repair synthesis, and finally reseal of the strand by a DNA ligase [134]. Overexpression of two key genes involved in the early steps of the NER process, ERCC1 and XPC, is associated with liver fibrogenesis and cancer and could be related to the well-recognized resistance of HCC to chemotherapeutics [135]. Several studies have revealed multiple genetic alterations of the mismatch repair (MMR) genes in hepatocarcinogenesis [136]. Among the MMR genes, human Mut L homologues 1 and 2 (hMLH1 and hMSH2) play important roles in DNA repair [137-139]. Immunohistochemical studies of MMR genes in HCC are few [40, 140-143]. HCC lacking both O6-methylguanineDNA methyltransferase (MGMT) and hMLH1 is correlated with an advanced stage and a poor prognosis. Mgmt-targeted $\left(\mathrm{Mgmt}^{-{ }^{-}}\right)$mice treated with alkylating agents develop HCC [144]. Reduced expression of hMSH2 and hMLH1 in both HCC and ANCLT suggests that this event occurs at early stages of HCV-related hepatocarcinogenesis. Moreover, the significant association between reduced expression of both MMR genes and poor histologic grades of the tumor claims that these proteins are involved in the process of cancer progression [136].

Although MRN complex has crucial physiologic activities in cell response to DNA damage, the role of defective MRN complex in HCC is still rarely described. A current study has reported that $\mathrm{HBV}$ infection downregulates the protein level of Mrell, and HCV core protein can interfere the formation of MRN complex by binding on Nbsl and inhibit subsequent activation of ATM and other DNA repair proteins $[116,117]$. Nevertheless, patients with occult HCV infection have been suggested to have high phosphorylated ATM, ATR, H2AX, and TP53, along with active recruitment of MRN complex, and further result in Bax-triggered mitochondria-mediated cellular apoptosis in lymphocyte [145]. These studies raised a question: which is a better strategy, to activate or to inhibit ATM activity, in treating HCC patients? Recently, Wang et al. revealed that GL331, a topoisomerase II inhibitor, activates autophosphorylation of ATM at S1981 and extends activations of DNA damage signaling pathways including TP53/p21 and Chk2/Cdc25A cascades to reach S phase arrest in HepG2 cells (Table 1) [146]. A small molecular inhibitor, CGK733, which targets kinase activity of ATM, can obviously reverse the resistance of HepG2 to taxol treatment (Tables 1 and 3) [147]. Besides, a synthetic cytotoxic effect was obtained in HepG2 cells when cotreated with sorafenib (multikinase inhibitor) and KU55933 (ATM inhibitor) (Tables 2 and 3) [148]. These results suggest that the ATM signaling pathway may serve as a novel target for the clinical treatment of HCC patients with chronic hepatitis B.

Genomic instability has long been proposed to be a mechanism by which a cell may acquire the necessary properties for invasion and metastasis [149]. The tumor suppressor TP53 has been well known in maintaining a stable genome under the toxic insults through its role in promoting cell-cycle checkpoints, DNA repair, and apoptosis [149]. It has been revealed that mutated T53 gene was found in approximately $50 \%$ of hepatoma cells [114]. And mutant TP53 often gains additional oncogenic functions that endow cells with growth and survival advantages and differences in radiosensitivity $[150,151]$. Recently, investigators have revealed that TP53mutated cells provide much more resistance to radiotherapy than TP53 null (Hep3B) and wild type TP53 cells (HepG2), suggesting the loss or mutation of TP53 proteins produced radioresistance [115]. It has been also reported that mutant TP53 can interact with Mrell and thereby impair the proper function of MRN complex (Table 1) [124]. Abrogation of Mrell function limits the phosphorylation and activation of ATM, resulting in bypassing of the G2/M DNA damage checkpoint. Loss of this checkpoint severely reduces the ability for efficient HR, resulting in less conservation of genetic information and accumulation of DNA damage and genetic errors [124].

PARP-1 is encoded by ADP-ribosyltransferase (ADPRT) gene, which regulates gene transcription, cell death signaling, and DNA repair through production of the posttranslational modification poly(ADP-ribose) [152], and its activation is one of the early responses to DNA damage [153]. Aberrant protein residue at V762A in PARP-1 has defective cellular response for oxidative DNA damage and contributes to prostate cancer susceptibility (Table 1) [154]. In addition, a recent study has showed that alteration of PARP-1 at residue A762A significantly depresses PARP-1 activity and is related to increased risk of cervical cancer (Table 1) [155]. In HCC, HBV may confer the development of HCC via octameric tandem repeats that can bind on PARP-1, and this interaction 
TABLE 1: Summary of aberrations of the DDR pathways and their subsequent effects.

\begin{tabular}{|c|c|c|c|}
\hline DNA repair protein & Mutation or polymorphism & Effect & Reference \\
\hline OGG1 & Ser 326 Cys & Increased risk of HCC. & [112] \\
\hline \multirow{3}{*}{ XRCC1 } & Arg 280 His & Increased susceptibility to HBV infection. & {$[112]$} \\
\hline & Arg 399 Gln & Increased risk of HCC. & {$[111]$} \\
\hline & Arg 194 Trp and Arg 280 His & Increased risk of bladder cancer. & {$[240]$} \\
\hline \multirow{3}{*}{ TP53 } & $\begin{array}{l}\text { Arg } 273 \text { His, Arg } 175 \text { His, and } \\
\text { Cys } 135 \text { Tyr }\end{array}$ & $\begin{array}{l}\text { TP53 GOF mutants stimulate EMT features through binding to and } \\
\text { transrepressing the promoter of miR-130b in endometrial cancer cells. }\end{array}$ & {$[241]$} \\
\hline & Arg $248 \operatorname{Trp}$ & $\begin{array}{c}\text { TP53 GOF mutant interacts with the nuclease Mrell and suppresses } \\
\text { the loading of the MRN complex to DNA DSB, subsequently } \\
\text { impairing the activation of ATM. }\end{array}$ & {$[124]$} \\
\hline & $\begin{array}{l}\text { Alteration of protein residues in } \\
\text { a.a. } 302-320\end{array}$ & $\begin{array}{l}\text { Retained associate with topoisomerase I and induced its activity } \\
\text { during times of DNA stress in a regulated fashion, facilitating DNA } \\
\text { repair. Suggested to lead to inappropriate topoisomerase I activity, } \\
\text { resulting in an increase in recombinogenic events. }\end{array}$ & {$[242]$} \\
\hline PARP-1 & Val 762 Ala & $\begin{array}{l}\text { Depressed PARP-1 activity is related to increased risk of cervical } \\
\text { cancer, smoking-related lung cancer, and prostate cancer } \\
\text { susceptibility. }\end{array}$ & {$[154,155,243]$} \\
\hline Mrell & C $1714 \mathrm{~T}$ & $\begin{array}{l}\text { Mutant Mre11 found at codon } 1714 \mathrm{C} \rightarrow \mathrm{T} \text {, which encodes a } \\
\text { prematurely truncated protein, is suggested to be eliminated by NMD. }\end{array}$ & {$[244]$} \\
\hline \multirow[t]{2}{*}{$\operatorname{Rad} 50$} & Ser 635 Gly & $\begin{array}{c}\text { Rad50 phosphosite-specific mutant supported normal activation of } \\
\text { ATM in Rad50-deficient cells but failed to correct radiosensitivity, } \\
\text { DNA DSB repair, and an S-phase checkpoint defect in } \\
\text { Rad50-deficient cells. }\end{array}$ & {$[245]$} \\
\hline & $\begin{array}{l}\text { Hook domain replace with six } \\
\text { a.a. residues from } 684 \text { to } 689 \text { : } \\
\text { Asn-Ala-Ala-Ile-Arg-Ser }\end{array}$ & $\begin{array}{l}\text { Rad50 zinc hook mutant leads to MRN complex which failed to load } \\
\text { to chromosomal DSB and exhibits very limited recruitment of DNA } \\
\text { repair proteins. }\end{array}$ & {$[246]$} \\
\hline \multirow{2}{*}{ Nbs1 } & $657 \mathrm{del} 5$ & $\begin{array}{l}\text { The Nbs1 657del5 founder allele is associated with an increased risk of } \\
\text { breast cancer. }\end{array}$ & {$[247]$} \\
\hline & Ser $706 \mathrm{X}$ & $\begin{array}{l}\text { Results in a premature stop at codon } 706 \text { and a truncated Nbsl protein } \\
\text { that lacks the extreme C-terminal ATM recruitment motif (ARM). }\end{array}$ & {$[248]$} \\
\hline \multirow{3}{*}{ ATM } & Ser 367 Ala and Ser 2996 Ala & $\begin{array}{l}\text { Both the S367A and S2996A mutants were defective in correcting } \\
\text { radioresistant DNA synthesis in A-T cells. }\end{array}$ & {$[249]$} \\
\hline & Ser 1893 Ala & $\begin{array}{l}\text { Defective activation of ATM was manifested as defective substrate } \\
\text { phosphorylation of TP53, Chk2, Nbs1, and SMCI in A-T cells } \\
\text { transfected with ATM S1893A mutant failed to correct } \\
\text { radiosensitivity, radiation-induced chromosome aberrations, and the } \\
\text { defective G2/M checkpoint. }\end{array}$ & {$[250]$} \\
\hline & Ser 1981 Ala & $\begin{array}{c}\text { ATM is sequestered with a dimer or multimer with its kinase domain } \\
\text { bound to an internal domain of a neighbouring ATM molecule } \\
\text { containing serine 1981. A mutation occurs at autophosphorylation } \\
\text { site, which leads to ATM unable to be released from other ATM } \\
\text { molecules, and fails to phosphorylate other cellular substrates while } \\
\text { DNA is damaged. }\end{array}$ & {$[251]$} \\
\hline
\end{tabular}

suppressed the DNA repair activity of PARP-1 and even increased the replication efficiency of HBV [156].

\section{Interplay between Viral Infection/Protein and DDR Pathways in HCC}

The relation of the virus to the development of HCC is through chronic hepatitis and cirrhosis [157]. A study directly assessing 8-oxo-deoxyguanosine in human liver revealed that both $\mathrm{HBV}$ and $\mathrm{HCV}$ infections were associated with
DNA damage [158]. Almost all patients with virus related HCC have an underlying cirrhosis. The hepatocyte necrosis and mitosis of chronic hepatitis favor nodular regeneration which, in appropriate circumstances, is followed by hepatocyte dysplasia and carcinoma [159]. Although nodular regeneration and cirrhosis remain the most important antecedents, the tumor can develop in the absence of cirrhosis. In this case, and by analogy with the HBV-like woodchuck chronic hepatitis, necroinflammatory activity may be an important requisite [160]. 
TABLE 2: Roles of DNA DSB repair proteins in HCC.

\begin{tabular}{|c|c|c|}
\hline DSB repair related proteins & Functions & Reference \\
\hline p53 binding protein 1 (53BP1) & $\begin{array}{l}\text { 53BP1 enhances TP53-mediated transcriptional activation via binding on DBD of TP53. } \\
\text { 53BP1 is also used as an indicator of DNA damage and has been shown to rapidly localize } \\
\text { to regions of DNA double-strand breaks. 53BP1 has a binding site for phosphorylated } \\
\text { H2AX and colocalizes with phosphorylated H2AX at sites of damage. }\end{array}$ & {$[252,253]$} \\
\hline Phospho-H2AX ( $\gamma \mathrm{H} 2 \mathrm{AX})$ & $\begin{array}{l}\mathrm{H} 2 \mathrm{AX} \text { is a potential regulator of DNA repair and is a useful tool for detecting DNA } \\
\text { damage, which also frequently occurs in preneoplastic lesions of HCC. }\end{array}$ & {$[186,254]$} \\
\hline Ku70 (XRCC6) & $\begin{array}{l}\text { Toll-like receptor } 4 \text { (TLR4) protects against HCC carcinogenesis by enhancing the } \\
\text { expression and function of DNA repair protein Ku70. Ectopic expression of Ku70 protects } \\
\text { against HCC initiation and progression by restoring the cellular senescent response, } \\
\text { decreases DNA damage, and promotes programmed cell death in TLR4-deficient livers. }\end{array}$ & {$[255,256]$} \\
\hline Ku80 (XRCC5) & $\begin{array}{c}\text { Overexpression of Ku80 obviously inhibits cell proliferation ability of } \mathrm{HCC} \text { cells, } \\
\text { SMMC7721, in vitro and in vivo, through functions as a tumor suppressor by inducing } \\
\text { S-phase arrest in a TP53-dependent pathway. }\end{array}$ & {$[257]$} \\
\hline DNA-PKcs & $\begin{array}{l}\text { Tissue staining results showed that the highest ratio of DNA-PKcs positive expressing } \\
\text { cells was detected in HCC than in cholangioadeno carcinomas biliary } \\
\text { cystadenocarcinomas. }\end{array}$ & [258] \\
\hline $\begin{array}{l}\text { Ataxia telangiectasia mutated } \\
\text { kinase (ATM) }\end{array}$ & $\begin{array}{l}\text { Autophosphorylation of ATM at S1981 extends activations of DNA damage signaling } \\
\text { pathways to reach S phase arrest in HepG2 cells. Inhibited activity of ATM improves the } \\
\text { cytotoxicity of taxol and serafenib in HepG2 cells. }\end{array}$ & {$[146-148]$} \\
\hline
\end{tabular}

TABLE 3: Summary of the involvement of the DDR pathways in potential therapy resistance in HCC.

\begin{tabular}{|c|c|c|c|}
\hline Protein & DNA repair pathway & Underlying effects & Reference \\
\hline Chk-1 & $\mathrm{HR}$ & $\begin{array}{l}\text { Shh ligand abolished RT-induced phosphorylation of Chk-1 as well } \\
\text { as impairing the repair of DNA DSB, which results in HCC cells, } \\
\text { HA22T, and Sk-Hep1, resistant to radiotherapy. }\end{array}$ & {$[232]$} \\
\hline Chk-2 & & $\begin{array}{l}\text { UCN-01 promotes the cytotoxicity of paclitaxel in paclitaxel } \\
\text { resistant HCC cells (SNU449, SNU398, SUN368, SNU354, and } \\
\text { HepG2 cells) via inhibiting activity of Chk-2. }\end{array}$ & {$[233,259]$} \\
\hline ECCR1 & NER & $\begin{array}{l}\text { HCC patients with increased nuclear staining of ERCC1 are } \\
\text { positively correlated with resistance of cisplatin treatment. }\end{array}$ & [236] \\
\hline $\mathrm{XPC}$ & & $\begin{array}{l}\text { Increased XPC is associated with liver fibrogenesis and cancer and } \\
\text { could be related to the well-recognized resistance of HCC to } \\
\text { chemotherapeutics. }\end{array}$ & {$[135]$} \\
\hline \multirow{2}{*}{ ATM } & \multirow[t]{2}{*}{ HR or NHEJ } & $\begin{array}{l}\text { Small molecular inhibitor, CGK733, which targets kinase activity } \\
\text { of ATM can obviously reverse HBV-positive HCC cells, }\end{array}$ & {$[147]$} \\
\hline & & $\begin{array}{l}\text { KU55933, ATM inhibitor cotreat with sorafenib, multikinase } \\
\text { inhibitor, shows synthetic cytotoxicity to HepG2 cells. }\end{array}$ & {$[148]$} \\
\hline
\end{tabular}

3.1. $H B V$. Chronic infection with $\mathrm{HBV}$ is a major risk factor for the development of HCC. The virus encodes a $17 \mathrm{kDa}$ protein, $\mathrm{HBx}$, which is thought to be involved in the development of HBV-associated HCC [161]. Epidemiologic studies have shown that chronic HBV infection is associated with a 100fold increase in the risk for HCC development relative to noncarriers, placing HBV in the forefront among known human carcinogens $[162,163]$. The integration of HBV DNA into hepatocytes is an integral step for persistent viral infection that leads to chronic hepatitis B infection, which ultimately causes HCC [164]. Viral DNA integration rearranges both host and viral genes, leading to the production of altered protein products and making hepatocytes more susceptible to HCC [165]. In addition, the insertion of viral genome may result in chromosome deletions and other general genomic instability [24] that activates several pathways switching on
HCC development [166]. As HBV is a DNA virus which integrates its genome inside the host genome, during $\mathrm{HBV}$ infection, viral replication occurs inside infected hepatocytes within viral capsids. In this manner, viral genome conceals itself from pattern recognition receptors (PRRs), of innate immune system, preventing the detection of initial HBV infectious particles [167] PPRs including Toll-like receptors (TLRs) $[168,169]$ that recognize the pathogen-associated molecular patterns leading to a change of macrophage phenotype. These macrophages secrete ROS, such as type I interferons (IFNs) (IFN- $\alpha$ and IFN- $\beta$ ), NO, and other cytokines and chemokines. It was studied that the general production of $\mathrm{NO}$ and ROS by activated macrophages may also cause hepatocytes destruction [170]. ROS can cause oxidative protein and DNA damage [171]. ROS also affects the central cellular processes such as apoptosis and proliferation 
leading to the development of cancer [172]. Genes that are involved in DNA damage such as CCND1, CDKN1A (p21CIP1/WAF1), MSH2, MSH3, TP53, and XIAP [173] along with modified gene expression and mutations are all required participants in the process of carcinogenesis. It was found that oxidative stress is associated with hepatitis B activity and XRCC1 gene is putatively associated with DNA damage [112].

Studies with transgenic mice provide conflicting results. Some $\mathrm{X}$ protein of $\mathrm{HBV}(\mathrm{HBx})$ transgenic mice develop liver cancer [174], while others do not [175-177]. However, HBx can serve as a cofactor for HCC in those transgenic mice that do not develop spontaneous tumors [176, 178, 179]. A cofactor role for the X protein is also observed in woodchuck hepatitis virus transgenic mice that do not spontaneously develop liver tumors [180]. Integrated viral DNA sequences might act in cis to modify host gene expression or encode viral proteins that may interfere with normal cellular functions either directly or indirectly. Accordingly, the inactivation of cellular proteins by viral proteins has been proposed as a potential mechanism of malignant transformation of hepatocytes by HBV [181]. Recent studies have shown that the HBx binds to cellular TP53 $[182,183]$ and, in vitro, inhibits TP53 sequencespecific DNA binding, TP53 transcriptional activity, and its association with the transcriptional factor ERCC3. Previous discussion showed that HBx antigen also participates in processes that are associated with the progression of chronic liver disease, including angiogenesis and fibrosis. Moreover, $\mathrm{HBx}$ expression affects DNA repair in a TP53-dependent manner [184]. Binding of HBx on TP53 leads to inhibition of TP53dependent DNA repair, thereby DNA damage accumulation in HBV-infected cells, and subsequently depressed TP53dependent apoptosis [183, 185, 186]. Furthermore, recent study has also indicated that HBsAg disrupts promyelocytic leukemia- (PML-) mediated DSB HR repair or apoptosis, which may facilitate hepatocarcinogenesis [18]. Based on these data, it has been suggested that HBV may affect a wide range of TP53 functions [183]. ATM and ATR kinases phosphorylate Ser-15 and Ser-20 of p53 following DNA damage $[187,188]$. HBx also sensitizes hepatocytes to $\mathrm{p} 53$ apoptosis via activation of the p38MAPK pathway, which couples p53 stabilization and p53 activation, by E2F1 induction and ATR activation, respectively [189]. In addition, $\mathrm{HBx}$ can impair the ATR-dependent phosphorylation of Chk1 and monoubiquitination of FANCD2. Overexpression of ATR reverts the MMC-induced phenotype of Chk1 and FANCD2 in HBx transformed cells [190]. The defect of intra-S-phase checkpoint may further result in accumulation of genomic instability. Many pathways of cellular immune system are activated during HBV infection. The deregulation of signaling pathways including MAPKs, TP53, sex steroid, Wnt $/ \beta$ catenin, transforming growth factor $\beta$ (TGF $\beta$ ), PI3 K/AKT, cytokines, NF- $\kappa \mathrm{B}$, and Hedgehog $(\mathrm{Hh})$ were found to be closely related with HCC development [191]. In addition, HBV heat shock proteins can upregulate three dominant groups of genes including oxidative and metabolic stress and growth and apoptosis-related genes [192]. The level of inflammatory cytokines such as IL- 6 is also found to be increased in HCC cells [193]. Level of IL-6 may also predict the shift from viral hepatitis to HCC in humans [194] due to Hh signal activation. It has been documented that the expression of $\mathrm{HBx}$ and $\mathrm{Hh}$ is highly correlated in human liver cancer cell lines [195].

3.2. $\mathrm{HCV}$. HCV infects more than 170 million people in the world. The importance of HCV infection in HCC and non-Hodgkin's B-cell lymphomas has been well documented $[196,197]$, indicating that HCV is a unique nonretroviral oncogenic RNA virus. From the genetic perspective, cancer represents the phenotypic consequence of the accumulation of mutations or deletions of DNA involving the inactivation of tumor suppressor genes and the activation of oncogenes by a stepwise process. It has recently demonstrated that HCV infection induces DNA damage that leads to a mutator phenotype [198]. In addition, HCV infection is able to cause DSBs and to enhance the mutation frequency of cellular genes, including protooncogenes and immunoglobulin genes [199]. $\mathrm{HCV}$-induced inflammation and oxidative stress have been also implicated as risk factors for liver damage and cancer development [200-202]. Patients with greater intrahepatic oxidative stress have a higher incidence of HCC recurrence [203]. Generally, HCV infection can induce the production of total $\mathrm{NO}$, that is, $\mathrm{NO}_{\mathrm{X}}$ which includes both nitrites $\left(\mathrm{NO}_{2}^{-}\right)$ and nitrates $\left(\mathrm{NO}_{3}{ }^{-}\right)$; there is an association between the viral load and the level of $\mathrm{NO}_{X}$ in the serum of HCV-infected patients [204]. Enhanced levels of inducible nitric oxide synthase (iNOS) expression (implying excessive NO formation) in the liver of HCV-infected patients also positively correlated with viral load and severity of hepatic inflammation [94]. In several human gastrointestinal neoplasms, including HCVassociated HCC, the immunologic (type II) isoform of NO synthase (NOS), that is, inducible NOS (iNOS), which generates $\mathrm{NO}$ from L-arginine in inflamed tissues, is elevated [205]. The enhanced levels of iNOS in HCV-associated T lymphocytes correlated with the high level of expression of HCV proteins [206]. Other observations supported this finding [207-209] and suggested that an important treatment option may include modulation of NO metabolism to prevent HCC pathogenesis and improve patient outcomes [207]. Therefore, one of the means by which HCV exerts its effects upon infected cells is likely oxidative stress, including NO production. Furthermore, Maki et al. [203] demonstrated that HCV-induced inflammation causes oxidative DNA damage and promotes hepatocarcinogenesis. In particular, generation of ROS and NOS associated with the decreased antioxidant defense seemed to promote the development and progression of hepatic and extrahepatic complications of HCV infection [210].

The HCV genome contains a large open reading frame encoding a polyprotein precursor of 3,010 to 3,033 amino acids and an untranslated region at the 59 and 39 ends of the genome. This polyprotein is processed into at least 10 proteins, 4 of which are structural proteins (core, E1, E2, and p7) and 6 nonstructural (NS) proteins (NS2, NS3, NS4A, NS4B, NS5A, and NS5B) in the order from the 59 end [211214]. HCV core protein activated SRE-, NF- $\kappa$ B-, and AP1-associated signals, and NS4B protein activated the NF$\kappa \mathrm{B}$-associated signal [100]. Interestingly, $\mathrm{HCV}$ core protein 
also binds to the Nbs1 protein and inhibits the formation of the Mre11/Nbs1/Rad50 complex, thereby affecting ATM activation and inhibiting DNA binding of repair enzymes. These data indicate that HCV infection inhibits multiple DNA repair processes to potentiate chromosome instability in both monocytes and hepatocytes. These effects may explain the oncogenicity and immunological perturbation of $\mathrm{HCV}$ infection [117]. Moreover, replication of both genomelength HCV RNA (HCV-O, genotype $1 \mathrm{~b}$ ) and the subgenomic replicon RNA is notably suppressed in ATM- or Chk2knockdown cells. HCV NS3-NS4A interacted with ATM and HCV NS5B interacted with both ATM and Chk2. These results suggest that the ATM signaling pathway is critical for HCV RNA replication and may represent a novel target for the clinical treatment of patients with chronic hepatitis $\mathrm{C}$ [215].

\section{DDR-Based Therapy Resistance in HCC}

Dysfunction of one DNA repair pathway may be compensated for by the function of another compensatory DDR pathway, which may be increased and may contribute to resistance to DNA-damaging chemotherapy and radiotherapy [10]. Human cancers exhibit genomic instability and an increased mutation rate due to underlying defects in DNA repair. Cancer cells are often defective in one of six major DNA repair pathways, namely, mismatch repair (MMR), BER, nucleotide excision repair (NER), HR, NHEJ, and translesion synthesis (TLS) [216]. Dysregulation of DNA damage repair and signaling to cell-cycle checkpoints, known as the DDR, is associated with a predisposition to cancer and affects responses to DNA-damaging anticancer therapy.

HCC has been known as one of the most lethal human malignancies, due to the difficulty of early detection, chemoresistance, and radioresistance [217, 218], and is characterized by active angiogenesis and metastasis, which account for rapid recurrence and poor survival [219]. Transarterial embolization (with or without chemotherapy) has been a general treatment choice for unresectable HCC through and is the standard of care for patients with preserved liver function and asymptomatic, noninvasive multinodular HCC confined to the liver [220, 221]. However, hypoxia also has been revealed to be associated with proliferation, angiogenesis, epithelial mesenchymal transition (EMT), a critical process for tumor invasion, and metastasis as well as chemoresistance and radioresistance in HCC [219, 222, 223]. Additionally, HCC is unique as it frequently reoccurs after treatment irrespective of the different etiological factors including $\mathrm{HBV}$ and $\mathrm{C} \mathrm{HCV}$, alcohol abuse, and nonalcoholic steatohepatitis [224-226]. One possible reason for the frequent recurrence of HCC might be due to many patients being affected with hepatitis virus-associated chronic liver inflammation [224, 227].

DNA damaging agents are widely used in treatment of hematological malignancies and solid tumors [228]. However, DDR also protects against genomic instability, and may enable cancer to become resistant to IR and chemotherapy drugs by enhanced DNA repair of the lesions [229, 230].
In addition, the development and progression of HCC is significantly correlated to the accumulation of genomic alterations [231]. Sonic hedgehog (Shh) ligand induced signaling is critical to embryogenesis and resistance to chemotherapy. Recent study showed that HCC cells, HA22T, and Sk-Hep1 are resistant to radiotherapy upon treatment of Shh ligand and reduced the radiotherapy-induced phosphorylation of Chk-1 as well as impairing the repair of DNA DSB. This phenomenon can be partly reversed by Shh antibody neutralization, suggesting that activation of Shh signaling protects HCC cells against ionizing radiation in an autocrine manner. Impairment of DNA damage repair might involve mechanism of Shh-induced radioresistance [232]. Inhibition of G2 DNA damage checkpoint by UCN-01 also promotes the cytotoxicity of paclitaxel in paclitaxel resistant HCC cells (SNU449, SNU398, SUN368, SNU354, and HepG2 cells) [233]. Excision repair cross complementation group 1 (ECCR1) belong to the nucleotide excision repair (NER) pathway and are essential to the repair of cisplatin DNA adducts [234]. Ueda et al. indicated that high nuclear staining of ECCR1 was found in 33\% of paraffin-embedded HCC tissue $(n=43)$, which is positively associated with succinic dehydrogenase, a major target aimed by cisplatin in mitochondria [235] and resistance to treatment of cisplatin [236]. A previous study has shown that overexpression of two NER genes, ERCC1 and XPC, is associated with liver fibrogenesis and cancer and could be related to the well-recognized resistance of HCC to chemotherapeutics [135]. It has been implicated that molecules involved in DNA repair or cell cycle checkpoints can be targets to enhance tumor radiosensitivity [237]. Taken together, these observations suggest that the drugs targeting DNA repair related proteins may be applicable to improve radioresistance and chemoresistance of HCC.

\section{Conclusions}

The accumulation of genetic alterations and genomic instability, partly resulted from causing DNA damages of HCCassociated risk factors and a concomitant failure of repairing lesions, is currently regarded as a common feature of HCC [231]. These risk factors have been proposed directly or indirectly to form DNA adducts and to produce ROS and NOS, which in turn cause DNA damage and lead to gene mutations, thus fostering neoplastic transformation. In addition, they can also target certain genes of the DDR pathways through indirect induction of multiple oncogenic signaling to counter the DDR pathways or through their own proteins to interrupt the DDR genes. For instance, it is now clear that $\mathrm{HBV}$, probably through $\mathrm{HBx}$, potentiates damage to DNA in infected cells, probably by inhibiting various aspects of the DDR. As many other viruses, HBV inactivates TP53 following infection. HBx binds directly to TP53 and inhibits its transcriptional activation properties $[182,238]$. It also inhibits the association of TP53 with transcription factors such as ERCC3/XPD and ERCC2/XPB $[183,239]$ and, as a consequence, abrogates TP53-induced apoptosis [183]. Since TP53 plays a key role in maintenance of the integrity of the genome, such a mechanism of TP53 
inactivation would establish a direct link between HBV infection and the malignant transformation of hepatocytes. More interestingly, DNA damages can also increase viral DNA integration into the host genome [23] and further induce genomic instability [24-26]. These studies straightly point out the importance of these risk-factors-associated genetic alterations, genomic instability, and alterations of the DDR pathways in HCC development and treatment. On the other hand, the reason why HCC is one of the most lethal human malignancies is at least in part due to its easy production of chemoresistance and radioresistance [217, 218]. Although DDR may protect against genomic instability, DDR also helps cancer to become resistant to IR and chemotherapy drugs by enhancing DNA repair of the DNA lesions [229, 230]. Furthermore, various DDR pathways can compensate for each other and contribute to resistance to DNA-damaging chemotherapy and radiotherapy $[10,229,230]$. It has been implicated that molecules involved in DNA repair or cell cycle checkpoints can be targets to enhance tumor radiosensitivity [237].

Taken together, a better understanding of the involvement of DDR in HCC may help us to develop the strategies for treatment or prevention of HCC. The development of drugs targeting DDR pathways may be applicable to improve radioresistance and chemoresistance of HCC and further prolong their survival. Herein, we present the critical involvement of the DDR pathways in HCC. Hopefully, this review will enforce the researchers and clinicians to further explore and validate the impacts and underlying mechanisms of DDR pathways in HCC.

\section{Conflict of Interests}

The authors declare that there is no conflict of interests regarding the publication of this paper.

\section{References}

[1] J. Ferlay, H.-R. Shin, F. Bray, D. Forman, C. Mathers, and D. M. Parkin, "Estimates of worldwide burden of cancer in 2008: GLOBOCAN 2008," International Journal of Cancer, vol. 127, no. 12, pp. 2893-2917, 2010.

[2] A. Jemal, F. Bray, M. M. Center, J. Ferlay, E. Ward, and D. Forman, "Global cancer statistics," CA: Cancer Journal for Clinicians, vol. 61, no. 2, pp. 69-90, 2011.

[3] L. E. Buitrago-Molina, S. Marhenke, T. Longerich et al., "The degree of liver injury determines the role of p21 in liver regeneration and hepatocarcinogenesis," Hepatology, vol. 58, no. 3, pp. 1143-1152, 2013.

[4] P. Fortini, C. Ferretti, and E. Dogliotti, "The response to DNA damage during differentiation: pathways and consequences," Mutation Research, vol. 743-744, pp. 160-168, 2013.

[5] M. F. Ogara, P. F. Sirkin, and L. Abel Carcagno, "Chromatin relaxation-mediated induction of p19INK4d increases the ability of cells to repair damaged DNA," PLoS ONE, vol. 8, no. 4, Article ID e61143, 2013.

[6] Y. H. Lee, C. Y. Kuo, J. M. Stark, H. M. Shih, and D. K. Ann, "HP1 promotes tumor suppressor BRCA1 functions during the DNA damage response," Nucleic Acids Research, vol. 41, no. 11, pp. 5784-5798, 2013.
[7] Y. L. Chung and M. L. Wu, "Promyelocytic leukemia protein links DNA damage response and repair to hepatitis B virus related hepatocarcinogenesis," Journal of Pathology, vol. 230, no. 4, pp. 377-387, 2013.

[8] S. Bayram, H. Akkiz, A. Bekar, E. Akgöllü, and S. Yildirim, "The significance of Exonuclease $1 \mathrm{~K} 589 \mathrm{E}$ polymorphism on hepatocellular carcinoma susceptibility in the Turkish population: a case-control study," Molecular Biology Reports, vol. 39, no. 5, pp. 5943-5951, 2012.

[9] C. M. Hsu, M. D. Yang, W. S. Chang et al., "The contribution of XRCC6/Ku70 to hepatocellular carcinoma in Taiwan," Anticancer Research, vol. 33, no. 2, pp. 529-535, 2013.

[10] N. J. Curtin, "DNA repair dysregulation from cancer driver to therapeutic target," Nature Reviews Cancer, vol. 12, no. 12, pp. 801-817, 2012.

[11] S. P. Lees-Miller and K. Meek, "Repair of DNA double strand breaks by non-homologous end joining," Biochimie, vol. 85, no. 11, pp. 1161-1173, 2003.

[12] M. El Idrissi, V. Hervieu, P. Merle, F. Mortreux, and E. Wattel, "Cause-specific telomere factors deregulation in hepatocellular carcinoma," Journal of Experimental and Clinical Cancer Research, vol. 32, article 64, 2013.

[13] J. Chen, B. Zhang, N. Wong et al., "Sirtuin 1 is upregulated in a subset of hepatocellular carcinomas where it is essential for telomere maintenance and tumor cell growth," Cancer Research, vol. 71, no. 12, pp. 4138-4149, 2011.

[14] R.-G. Zhang, J.-J. Zhao, L.-Q. Yang et al., "RNA interferencemediated hTERT inhibition enhances TRAIL-induced apoptosis in resistant hepatocellular carcinoma cells," Oncology Reports, vol. 23, no. 4, pp. 1013-1019, 2010.

[15] T. H. M. Chan, L. Chen, M. Liu et al., "Translationally controlled tumor protein induces mitotic defects and chromosome missegregation in hepatocellular carcinoma development," Hepatology, vol. 55, no. 2, pp. 491-505, 2012.

[16] S. Martin-Lluesma, C. Schaeffer, E. I. Robert et al., "Hepatitis $\mathrm{B}$ virus $\mathrm{X}$ protein affects $\mathrm{S}$ phase progression leading to chromosome segregation defects by binding to damaged DNA binding protein 1," Hepatology, vol. 48, no. 5, pp. 1467-1476, 2008

[17] H. X. Yan, H. P. Wu, H. L. Zhang et al., "p53 promotes inflammation-associated hepatocarcinogenesis by inducing HMGB1 release," Journal of Hepatology, vol. 59, no. 4, pp. 762768,2013

[18] Y. L. Chung, "Defective DNA damage response and repair in liver cells expressing hepatitis B virus surface antigen," The FASEB Journal, vol. 27, no. 6, pp. 2316-2327, 2013.

[19] P. Laurent-Puig and J. Zucman-Rossi, "Genetics of hepatocellular tumors," Oncogene, vol. 25, no. 27, pp. 3778-3786, 2006.

[20] K. J. Schmitz, J. Wohlschlaeger, H. Lang et al., "Activation of the ERK and AKT signalling pathway predicts poor prognosis in hepatocellular carcinoma and ERK activation in cancer tissue is associated with hepatitis C virus infection," Journal of Hepatology, vol. 48, no. 1, pp. 83-90, 2008.

[21] Y. Edamoto, A. Hara, W. Biernat et al., "Alterations of RB1, p53 and Wnt pathways in hepatocellular carcinomas associated with hepatitis C, hepatitis B and alcoholic liver cirrhosis," International Journal of Cancer, vol. 106, no. 3, pp. 334-341, 2003.

[22] K. Koike, "Pathogenesis of HCV-associated HCC: dual-pass carcinogenesis through activation of oxidative stress and intracellular signaling," Hepatology Research, vol. 37, supplement 2, pp. S115-S120, 2007. 
[23] M. Dandri, M. R. Burda, A. Bürkle et al., "Increase in de novo HBV DNA integrations in response to oxidative DNA damage or inhibition of poly(ADP-ribosyl)ation," Hepatology, vol. 35, no. 1, pp. 217-223, 2002.

[24] D. Kremsdorf, P. Soussan, P. Paterlini-Brechot, and C. Brechot, "Hepatitis B virus-related hepatocellular carcinoma: paradigms for viral-related human carcinogenesis," Oncogene, vol. 25, no. 27, pp. 3823-3833, 2006.

[25] Y. Shaul, P. D. Garcia, S. Schonberg, and W. J. Rutter, "Integration of hepatitis B virus DNA in chromosome-specific satellite sequences," Journal of Virology, vol. 59, no. 3, pp. 731-734, 1986.

[26] I. Berger and Y. Shaul, "Integration of hepatitis B virus: analysis of unoccupied sites," Journal of Virology, vol. 61, no. 4, pp. 1180$1186,1987$.

[27] M. Salvucci, A. Lemoine, D. Azoulay et al., "Frequent microsatellite instability in post hepatitis B viral cirrhosis," Oncogene, vol. 13, no. 12, pp. 2681-2685, 1996.

[28] A. Karachristos, T. Liloglou, J. K. Field, E. Deligiorgi, E. Kouskouni, and D. A. Spandidos, "Microsatellite instability and p53 mutations in hepatocellular carcinoma," Molecular Cell Biology Research Communications, vol. 2, no. 3, pp. 155-161, 1999.

[29] M. P. Dore, G. Realdi, D. Mura et al., "Genomic instability in chronic viral hepatitis and hepatocellular carcinoma," Human Pathology, vol. 32, no. 7, pp. 698-703, 2001.

[30] H. Kawai, T. Suda, Y. Aoyagi et al., "Quantitative evaluation of genomic instability as a possible predictor for development of hepatocellular carcinoma: comparison of loss of heterozygosity and replication error," Hepatology, vol. 31, no. 6, pp. 1246-1250, 2000.

[31] Y. Kondo, Y. Kanai, M. Sakamoto, M. Mizokami, R. Ueda, and S. Hirohashi, "Genetic instability and aberrant DNA methylation in chronic hepatitis and cirrhosis: a comprehensive study of loss of heterozygosity and microsatellite instability at 39 loci and DNA hypermethylation on $8 \mathrm{CpG}$ islands in microdissected specimens from patients with hepatocellular carcinoma," Hepatology, vol. 32, no. 5, pp. 970-979, 2000.

[32] M. Salvucci, A. Lemoine, R. Saffroy et al., "Microsatellite instability in European hepatocellular carcinoma," Oncogene, vol. 18, no. 1, pp. 181-187, 1999.

[33] G. A. Macdonald, J. K. Greenson, K. Saito, S. P. Cherian, H. D. Appelman, and C. Richard Boland, "Microsatellite instability and loss of heterozygosity at DNA mismatch repair gene loci occurs during hepatic carcinogenesis," Hepatology, vol. 28, no. 1, pp. 90-97, 1998.

[34] I. Nozaki, R. Ohashi, N. Matsubara et al., "Microsatellite instability correlates with normal expression of cyclin $\mathrm{E}$ in hepatocellular carcinomas," International journal of oncology, vol. 18, no. 6, pp. 1265-1269, 2001.

[35] K. Takagi, M. Esumi, S. Takano, and S. Iwai, "Replication error frequencies in primary hepatocellular carcinoma: a comparison of solitary primary versus multiple primary cancers," Liver, vol. 18, no. 4, pp. 272-276, 1998.

[36] M. Yano, T. Asahara, K. Dohi, T. Mizuno, K. S. Iwamoto, and T. Seyama, "Close correlation between a p53 or hMSH2 gene mutation in the tumor and survival of hepatocellular carcinoma patients," International Journal of Oncology, vol. 14, no. 3, pp. 447-451, 1999.

[37] Y. M. Park, J. Y. Choi, S. H. Bae et al., "Microsatellite instability and mutations of E2F-4 in hepatocellular carcinoma from Korea," Hepatology Research, vol. 17, no. 2, pp. 102-111, 2000.
[38] C. Martins, M. A. Kedda, and M. C. Kew, "Characterization of six tumor suppressor genes and microsatellite instability in hepatocellular carcinoma in southern African blacks," World Journal of Gastroenterology, vol. 5, no. 6, pp. 470-476, 1999.

[39] P. Laurent-Puig, P. Legoix, O. Bluteau et al., "Genetic alterations associated with hepatocellular carcinomas define distinct pathways of hepatocarcinogenesis," Gastroenterology, vol. 120, no. 7, pp. 1763-1773, 2001.

[40] L. Wang, A. Bani-Hani, D. P. Montoya et al., "hMLH1 and hMSH2 expression in human hepatocellular carcinoma," International journal of oncology, vol. 19, no. 3, pp. 567-570, 2001.

[41] H. Yamamoto, F. Itoh, H. Fukushima et al., "Infrequent widespread microsatellite instability in hepatocellular carcinomas," International journal of oncology, vol. 16, no. 3, pp. 543$547,2000$.

[42] Y. Kondo, Y. Kanai, M. Sakamoto, M. Mizokami, R. Ueda, and S. Hirohashi, "Microsatellite instability associated with hepatocarcinogenesis," Journal of Hepatology, vol. 31, no. 3, pp. 529-536, 1999.

[43] A. Saeki, S. Tamura, N. Ito et al., "Lack of frameshift mutations at coding mononucleotide repeats in hepatocellular carcinoma in Japanese patients," Cancer, vol. 88, no. 5, pp. 1025-1029, 2000.

[44] Z. Piao, H. Kim, S. Malkhosyan, and C. Park, "Frequent chromosomal instability but no microsatellite instability in hepatocellular carcinomas," International journal of oncology, vol. 17, no. 3, pp. 507-512, 2000.

[45] M. Roncalli, P. Bianchi, G. C. Grimaldi et al., "Fractional allelic loss in non-end-stage cirrhosis: correlations with hepatocellular carcinoma development during follow-up," Hepatology, vol. 31, no. 4, pp. 846-850, 2000.

[46] M. Maggioni, G. Coggi, B. Cassani et al., "Molecular changes in hepatocellular dysplastic nodules on microdissected liver biopsies," Hepatology, vol. 32, no. 5, pp. 942-946, 2000.

[47] G. Wang, Y. Zhao, X. Liu et al., "Allelic loss and gain, but not genomic instability, as the major somatic mutation in primary hepatocellular carcinoma," Genes Chromosomes and Cancer, vol. 31, no. 3, pp. 221-227, 2001.

[48] T. Sato, A. Tanigami, K. Yamakawa et al., "Allelotype of breast cancer: cumulative allele losses promote tumor progression in primary breast cancer," Cancer Research, vol. 50, no. 22, pp. 7184-7189, 1990.

[49] R. Morita, J. Ishikawa, M. Tsutsumi et al., "Allelotype of renal cell carcinoma," Cancer Research, vol. 51, no. 3, pp. 820-823, 1991.

[50] M. Fujimori, T. Tokino, O. Hino et al., "Allelotype study of primary hepatocellular carcinoma," Cancer Research, vol. 51, no. 1, pp. 89-93, 1991.

[51] S. Yokoyama, K. Yamakawa, E. Tsuchiya, M. Murata, S. Sakiyama, and Y. Nakamura, "Deletion mapping on the short arm of chromosome 3 in squamous cell carcinoma and adenocarcinoma of the lung," Cancer Research, vol. 52, no. 4, pp. 873$877,1992$.

[52] Y. Miki, I. Nishisho, Y. Miyoshi et al., "Frequent loss of heterozygosity at the MCC locus on chromosome 5q21-22 in sporadic colorectal carcinomas," Japanese Journal of Cancer Research, vol. 82, no. 9, pp. 1003-1007, 1991.

[53] G. N. Wogan, S. S. Hecht, J. S. Felton, A. H. Conney, and L. A. Loeb, "Environmental and chemical carcinogenesis," Seminars in Cancer Biology, vol. 14, no. 6, pp. 473-486, 2004.

[54] C. P. Wild and R. Montesano, "A model of interaction: aflatoxins and hepatitis viruses in liver cancer aetiology and prevention," Cancer Letters, vol. 286, no. 1, pp. 22-28, 2009. 
[55] J. Martin and J.-F. Dufour, “Tumor suppressor and hepatocellular carcinoma," World Journal of Gastroenterology, vol. 14, no. 11, pp. 1720-1733, 2008.

[56] P. E. Jackson, S.-Y. Kuang, J.-B. Wang et al., "Prospective detection of codon 249 mutations in plasma of hepatocellular carcinoma patients," Carcinogenesis, vol. 24, no. 10, pp. 16571663, 2003.

[57] B. Bressac, M. Kew, J. Wands, and M. Ozturk, "Selective G to $\mathrm{T}$ mutations of $\mathrm{p} 53$ gene in hepatocellular carcinoma from southern Africa," Nature, vol. 350, no. 6317, pp. 429-431, 1991.

[58] R. Montesano, P. Hainaut, and C. P. Wild, "Hepatocellular carcinoma: from gene to public health," Journal of the National Cancer Institute, vol. 89, no. 24, pp. 1844-1851, 1997.

[59] I. C. Hsu, R. A. Metcalf, T. Sun, J. A. Welsh, N. J. Wang, and C. C. Harris, "Mutational hotspot in the p53 gene in human hepatocellular carcinomas," Nature, vol. 350 , no. 6317, pp. 427428, 1991.

[60] M. Ozturk, B. Bressac, A. Puisieux et al., "p53 mutation in hepatocellular carcinoma after aflatoxin exposure," The Lancet, vol. 338, no. 8779, pp. 1356-1359, 1991.

[61] M. C. Stern, D. M. Umbach, M. C. Yu, S. J. London, Z.-Q. Zhang, and J. A. Taylor, "Hepatitis B, aflatoxin B1, and p53 codon 249 mutation in hepatocellular carcinomas from Guangxi, People's Republic of China, and a meta-analysis of existing studies," Cancer Epidemiology Biomarkers and Prevention, vol. 10, no. 6, pp. 617-625, 2001.

[62] S. Egal, A. Hounsa, Y. Y. Gong et al., "Dietary exposure to aflatoxin from maize and groundnut in young children from Benin and Togo, West Africa," International Journal of Food Microbiology, vol. 104, no. 2, pp. 215-224, 2005.

[63] F. A. Obuseh, P. E. Jolly, A. Kulczycki et al., "Aflatoxin levels, plasma vitamins A and e concentrations, and their association with HIV and hepatitis B virus infections in Ghanaians: a crosssectional study," Journal of the International AIDS Society, vol. 14, no. 1, article no. 53, 2011.

[64] L. Lewis, M. Onsongo, H. Njapau et al., "Aflatoxin contamination of commercial maize products during an outbreak of acute aflatoxicosis in eastern and central Kenya," Environmental Health Perspectives, vol. 113, no. 12, pp. 1763-1767, 2005.

[65] N. Sutandyo, "Nutritional carcinogenesis," Acta medica Indonesiana, vol. 42, no. 1, pp. 36-42, 2010.

[66] R. A. Sharma and P. B. Farmer, "Biological relevance of adduct detection to the chemoprevention of cancer," Clinical Cancer Research, vol. 10, no. 15, pp. 4901-4912, 2004.

[67] J.-S. Wang and J. D. Groopman, "DNA damage by mycotoxins," Mutation Research: Fundamental and Molecular Mechanisms of Mutagenesis, vol. 424, no. 1-2, pp. 167-181, 1999.

[68] C. S. Lieber, "Alcohol and the liver: 1994 update," Gastroenterology, vol. 106, no. 4, pp. 1085-1105, 1994.

[69] F. Levi, "Cancer prevention: epidemiology and perspectives," European Journal of Cancer, vol. 35, no. 14, pp. 1912-1924, 1999.

[70] S. Kubo, H. Kinoshita, K. Hirohashi et al., "High malignancy of hepatocellular carcinoma in alcoholic patients with hepatitis $\mathrm{C}$ virus," Surgery, vol. 121, no. 4, pp. 425-429, 1997.

[71] G. Pöschl and H. K. Seitz, "Alcohol and cancer," Alcohol and Alcoholism, vol. 39, no. 3, pp. 155-165, 2004.

[72] J.-L. Fang and C. E. Vaca, "Development of a32P-postlabelling method for the analysis of adducts arising through the reaction of acetaldehyde with 2'-deoxyguanosine-3'-monophosphate and DNA," Carcinogenesis, vol. 16, no. 9, pp. 2177-2185, 1995.
[73] C. E. Vaca, J.-L. Fang, and E. K. H. Schweda, "Studies of the reaction of acetaldehyde with deoxynucleosides," ChemicoBiological Interactions, vol. 98, no. 1, pp. 51-67, 1995.

[74] L. L. Woo, P. A. Egner, C. L. Belanger et al., "Aflatoxin B1-DNA adduct formation and mutagenicity in livers of neonatal male and female B6C3F1 mice," Toxicological Sciences, vol. 122, no. 1, pp. 38-44, 2011.

[75] Y. J. Zhang, "Interactions of chemical carcinogens and genetic variation in hepatocellular carcinoma," World Journal of Hepatology, vol. 2, no. 3, pp. 94-102, 2010.

[76] C. Berasain, J. Castillo, M. J. Perugorria, M. U. Latasa, J. Prieto, and M. A. Avila, "Inflammation and liver cancer: new molecular links," Annals of the New York Academy of Sciences, vol. 1155, pp. 206-221, 2009.

[77] C. Porta, E. Riboldi, and A. Sica, "Mechanisms linking pathogens-associated inflammation and cancer," Cancer Letters, vol. 305, no. 2, pp. 250-262, 2011.

[78] E. E. Calle and R. Kaaks, "Overweight, obesity and cancer: epidemiological evidence and proposed mechanisms," Nature Reviews Cancer, vol. 4, no. 8, pp. 579-591, 2004.

[79] B. Q. Starley, C. J. Calcagno, and S. A. Harrison, "Nonalcoholic fatty liver disease and hepatocellular carcinoma: a weighty connection," Hepatology, vol. 51, no. 5, pp. 1820-1832, 2010.

[80] S. Takamatsu, N. Noguchi, A. Kudoh et al., "Influence of risk factors for metabolic syndrome and non-alcoholic fatty liver disease on the progression and prognosis of hepatocellular carcinoma," Hepato-Gastroenterology, vol. 55, no. 82-83, pp. 609-614, 2008.

[81] R. S. Ahima and S. Y. Osei, "Leptin signaling," Physiology and Behavior, vol. 81, no. 2, pp. 223-241, 2004.

[82] F. Marra, "Leptin and liver fibrosis: a matter of fat," Gastroenterology, vol. 122, no. 5, pp. 1529-1532, 2002.

[83] Q. Cao, K. M. Mak, C. Ren, and C. S. Lieber, "Leptin stimulates tissue inhibitor of metalloproteinase-1 in human hepatic stellate cells. Respective roles of the JAK/STAT and JAK-mediated $\mathrm{H}_{2} \mathrm{O}_{2}$-dependent MAPK pathways," Journal of Biological Chemistry, vol. 279, no. 6, pp. 4292-4304, 2004.

[84] N. K. Saxena, M. A. Titus, X. Ding et al., "Leptin as a novel profibrogenic cytokine in hepatic stellate cells: mitogenesis and inhibition of apoptosis mediated by extracellular regulated kinase (Erk) and Akt phosphorylation," The FASEB Journal, vol. 18, no. 13, pp. 1612-1614, 2004.

[85] K. Ikejima, Y. Takei, H. Honda et al., "Leptin receptor-mediated signaling regulates hepatic fibrogenesis and remodeling of extracellular matrix in the rat," Gastroenterology, vol. 122, no. 5, pp. 1399-1410, 2002.

[86] E. Tsochatzis, G. V. Papatheodoridis, E. Hadziyannis et al., "Serum adipokine levels in chronic liver diseases: association of resistin levels with fibrosis severity," Scandinavian Journal of Gastroenterology, vol. 43, no. 9, pp. 1128-1136, 2008.

[87] A. Uygun, A. Kadayifci, Z. Yesilova et al., "Serum leptin levels in patients with nonalcoholic steatohepatitis," The American Journal of Gastroenterology, vol. 95, no. 12, pp. 3584-3589, 2000.

[88] Y.-Y. Wang and S.-Y. Lin, "Leptin in relation to hepatocellular carcinoma in patients with liver cirrhosis," Hormone Research, vol. 60, no. 4, pp. 185-190, 2003.

[89] Z. Li, W. Yuan, S. Ning, J. Li, W. Zhai, and S. Zhang, "Role of leptin receptor (LEPR) gene polymorphisms and haplotypes in susceptibility to hepatocellular carcinoma in subjects with chronic hepatitis B virus infection," Molecular Diagnosis and Therapy, vol. 16, no. 6, pp. 383-388, 2012. 
[90] N. K. Saxena, D. Sharma, X. Ding et al., "Concomitant activation of the JAK/STAT, PI3K/AKT, and ERK signaling is involved in leptin-mediated promotion of invasion and migration of hepatocellular carcinoma cells," Cancer Research, vol. 67, no. 6, pp. 2497-2507, 2007.

[91] R. H. Wiltrout, "Regulation and antimetastatic functions of liver-associated natural killer cells," Immunological Reviews, vol. 174, pp. 63-76, 2000.

[92] C. de Lalla, G. Galli, L. Aldrighetti et al., "Production of profibrotic cytokines by invariant NKT cells characterizes cirrhosis progression in chronic viral hepatitis," Journal of Immunology, vol. 173, no. 2, pp. 1417-1425, 2004.

[93] S. P. Hussain, L. J. Hofseth, and C. C. Harris, "Radical causes of cancer," Nature Reviews Cancer, vol. 3, no. 4, pp. 276-285, 2003.

[94] P. L. Majano and C. Garcia-Monzon, "Does nitric oxide play a pathogenic role in hepatitis C virus infection?" Cell Death and Differentiation, vol. 10, supplement 1, pp. S13-S15, 2003.

[95] P. C. Dedon and S. R. Tannenbaum, "Reactive nitrogen species in the chemical biology of inflammation," Archives of Biochemistry and Biophysics, vol. 423, no. 1, pp. 12-22, 2004.

[96] J. Cadet, T. Douki, and J.-L. Ravanat, “Oxidatively generated damage to the guanine moiety of DNA: mechanistic aspects and formation in cells," Accounts of Chemical Research, vol. 41, no. 8, pp. 1075-1083, 2008.

[97] W. L. Neeley and J. M. Essigmann, "Mechanisms of formation, genotoxicity, and mutation of guanine oxidation products," Chemical Research in Toxicology, vol. 19, no. 4, pp. 491-505, 2006.

[98] J. D. West and L. J. Marnett, "Endogenous reactive intermediates as modulators of cell signaling and cell death," Chemical Research in Toxicology, vol. 19, no. 2, pp. 173-194, 2006.

[99] Y. Wang, "Bulky DNA lesions induced by reactive oxygen species," Chemical Research in Toxicology, vol. 21, no. 2, pp. 276281, 2008.

[100] N. Kato, H. Yoshida, S. Kioko Ono-Nita et al., "Activation of intracellular signaling by hepatitis $\mathrm{B}$ and $\mathrm{C}$ viruses: $\mathrm{C}$-viral core is the most potent signal inducer," Hepatology, vol. 32, no. 2, pp. 405-412, 2000.

[101] E. Novo and M. Parola, "Redox mechanisms in hepatic chronic wound healing and fibrogenesis," Fibrogenesis Tissue Repair, vol. 1, no. 1, 2008.

[102] J. Wu and M. A. Zern, "Hepatic stellate cells: a target for the treatment of liver fibrosis," Journal of Gastroenterology, vol. 35, no. 9, pp. 665-672, 2000.

[103] R. Bataller, R. F. Schwabe, Y. H. Choi et al., "NADPH oxidase signal transduces angiotensin II in hepatic stellate cells and is critical in hepatic fibrosis," Journal of Clinical Investigation, vol. 112, no. 9, pp. 1383-1394, 2003.

[104] A. Budhu and W. W. Xin, "The role of cytokines in hepatocellular carcinoma," Journal of Leukocyte Biology, vol. 80, no. 6, pp. 1197-1213, 2006.

[105] G. C. Leonardi, S. Candido, M. Cervello et al., "The tumor microenvironment in hepatocellular carcinoma," International Journal of Oncology, vol. 40, no. 6, pp. 1733-1747, 2012.

[106] E. Pikarsky, R. M. Porat, I. Stein et al., "NF- $\kappa$ B functions as a tumour promoter in inflammation-associated cancer," Nature, vol. 431, no. 7007, pp. 461-466, 2004.

[107] T. Luedde and R. F. Schwabe, "NF- $\kappa \mathrm{B}$ in the liver-linking injury, fibrosis and hepatocellular carcinoma," Nature Reviews Gastroenterology and Hepatology, vol. 8, no. 2, pp. 108-118, 2011.
[108] C. C. Prosser, R. D. Yen, and J. Wu, "Molecular therapy for hepatic injury and fibrosis: where are we?" World Journal of Gastroenterology, vol. 12, no. 4, pp. 509-515, 2006.

[109] T. Adachi, H. Togashi, A. Suzuki et al., "NAD(P)H oxidase plays a crucial role in PDGF-induced proliferation of hepatic stellate cells," Hepatology, vol. 41, no. 6, pp. 1272-1281, 2005.

[110] M. Pinzani, L. Gesualdo, G. M. Sabbah, and H. E. Abboud, "Effects of platelet-derived growth factor and other polypeptide mitogens on DNA synthesis and growth of cultured rat liver fatstoring cells," Journal of Clinical Investigation, vol. 84, no. 6, pp. 1786-1793, 1989.

[111] H. Z. Pan, J. Liang, Z. Yu, L. M. Lun, H. Li, and Q. Wang, "Polymorphism of DNA repair gene XRCC1 and hepatocellular carcinoma risk in Chinese population," Asian Pacific Journal of Cancer Prevention, vol. 12, no. 11, pp. 2947-2950, 2011.

[112] T. Yuan, J. Wei, J. Luo, M. Liu, S. Deng, and P. Chen, "Polymorphisms of base-excision repair genes hOGG1 326cys and XRCC1 280His increase hepatocellular carcinoma risk," Digestive Diseases and Sciences, vol. 57, no. 9, pp. 2451-2457, 2012.

[113] W. Wang, S. Dang, Y. Li et al., "hOGG1 Ser326Cys polymorphism and risk of hepatocellular carcinoma among East Asians: a meta-analysis," PLoS ONE, vol. 8, no. 4, Article ID e60178, 2013.

[114] A. Puisieux, K. Galvin, F. Troalen et al., "Retinoblastoma and p53 tumor suppressor genes in human hepatoma cell lines," The FASEB Journal, vol. 7, no. 14, pp. 1407-1413, 1993.

[115] Y. Cun, N. Dai, C. Xiong et al., "Silencing of APE1 enhances sensitivity of human hepatocellular carcinoma cells to radiotherapy in vitro and in a xenograft model," PLoS ONE, vol. 8, no. 2, Article ID e55313, 2013.

[116] Y. Liu, N. Hou, F. Zhao et al., "HBV infection downregulated Mrell expression and induced genome instability," Wei Sheng wu Xue Bao, vol. 48, no. 8, pp. 1031-1034, 2008.

[117] K. Machida, G. Mcnamara, K. T.-H. Cheng et al., "Hepatitis $\mathrm{C}$ virus inhibits DNA damage repair through reactive oxygen and nitrogen species and by interfering with the ATMNBS1/Mre11/Rad50 DNA repair pathway in monocytes and hepatocytes," Journal of Immunology, vol. 185, no. 11, pp. 69856998, 2010.

[118] N. C. Teoh, Y. D. Yock, K. Swisshelm et al., "Defective DNA strand break repair causes chromosomal instability and accelerates liver carcinogenesis in mice," Hepatology, vol. 47, no. 6, pp. 2078-2088, 2008.

[119] N. Assenmacher and K.-P. Hopfner, "MRE11/RAD50/NBS1: complex activities," Chromosoma, vol. 113, no. 4, pp. 157-166, 2004.

[120] M. Furuse, Y. Nagase, H. Tsubouchi, K. Murakami-Murofushi, T. Shibata, and K. Ohta, "Distinct roles of two separable in vitro activities of yeast Mrell in mitotic and meiotic recombination," EMBO Journal, vol. 17, no. 21, pp. 6412-6425, 1998.

[121] J.-H. Lee and T. T. Paull, "ATM activation by DNA doublestrand breaks through the Mrel1-Rad50-Nbs1 complex," Science, vol. 308, no. 5721, pp. 551-554, 2005.

[122] S. P. Jackson, "Sensing and repairing DNA double-strand breaks," Carcinogenesis, vol. 23, no. 5, pp. 687-696, 2002.

[123] S. Zha, C. Boboila, and F. W. Alt, "Mrell: roles in DNA repair beyond homologous recombination," Nature Structural and Molecular Biology, vol. 16, no. 8, pp. 798-800, 2009.

[124] H. Song, M. Hollstein, and Y. Xu, "p53 gain-of-function cancer mutants induce genetic instability by inactivating ATM," Nature Cell Biology, vol. 9, no. 5, pp. 573-580, 2007. 
[125] I. Qadri, K. Fatima, and H. Abdel-Hafiz, "Hepatitis B virus $\mathrm{X}$ protein impedes the DNA repair via its association with transcription factor, TFIIH," BMC Microbiology, vol. 11, article 48, 2011.

[126] W. Wei, B. Li, M. A. Hanes, S. Kakar, X. Chen, and L. Liu, "S-nitrosylation from GSNOR deficiency impairs DNA repair and promotes hepatocarcinogenesis," Science Translational Medicine, vol. 2, no. 19, pp. 19-ra13, 2010.

[127] I. H. McKillop, D. M. Moran, X. Jin, and L. G. Koniaris, "Molecular Pathogenesis of Hepatocellular Carcinoma," Journal of Surgical Research, vol. 136, no. 1, pp. 125-135, 2006.

[128] J. Han, S. E. Hankinson, I. De Vivo et al., "A Prospective Study of XRCC1 Haplotypes and Their Interaction with Plasma Carotenoids on Breast Cancer Risk," Cancer Research, vol. 63, no. 23, pp. 8536-8541, 2003.

[129] H. Ide and M. Kotera, "Human DNA glycosylases involved in the repair of oxidatively damaged DNA," Biological and Pharmaceutical Bulletin, vol. 27, no. 4, pp. 480-485, 2004.

[130] H. Zhang, T. Mizumachi, J. Carcel-Trullols et al., "Targeting human 8-oxoguanine DNA glycosylase (hOGG1) to mitochondria enhances cisplatin cytotoxicity in hepatoma cells," Carcinogenesis, vol. 28, no. 8, pp. 1629-1637, 2007.

[131] S. Bose, D. M. Tripathi, Sukriti, P. Sakhuja, S. N. Kazim, and S. K. Sarin, "Genetic polymorphisms of CYP2E1 and DNA repair genes HOGG1 and XRCC1: association with hepatitis B related advanced liver disease and cancer," Gene, vol. 519, no. 2, pp. 231237, 2013.

[132] T. Kohno, K. Shinmura, M. Tosaka et al., "Genetic polymorphisms and alternative splicing of the hOGG1 gene, that is involved in the repair of 8-hydroxyguanine in damaged DNA," Oncogene, vol. 16, no. 25, pp. 3219-3225, 1998.

[133] E. C. Friedberg, "How nucleotide excision repair protects against cancer," Nature Reviews Cancer, vol. 1, no. 1, pp. 22-33, 2001.

[134] R. D. Wood, "DNA repair in eukaryotes," Annual Review of Biochemistry, vol. 65, pp. 135-167, 1996.

[135] A. Fautrel, L. Andrieux, O. Musso, K. Boudjema, A. Guillouzo, and S. Langouët, "Overexpression of the two nucleotide excision repair genes ERCC1 and XPC in human hepatocellular carcinoma," Journal of Hepatology, vol. 43, no. 2, pp. 288-293, 2005.

[136] T. E. A. Helal, N. S. Khamis, T. M. El-Sharkawy, O. H. Nada, and N. A. Radwan, "Immunohistochemical expression of mismatch repair genes (hMSH2 and hMLH1) in hepatocellular carcinoma in Egypt," APMIS, vol. 118, no. 12, pp. 934-940, 2010.

[137] F. S. Leach, N. C. Nicolaides, N. Papadopoulos et al., "Mutations of a mutS homolog in hereditary nonpolyposis colorectal cancer," Cell, vol. 75, no. 6, pp. 1215-1225, 1993.

[138] N. Papadopoulos, N. C. Nicolaides, Y.-F. Wei et al., "Mutation of a mutL homolog in hereditary colon cancer," Science, vol. 263, no. 5153, pp. 1625-1629, 1994.

[139] R. Fishel, M. K. Lescoe, M. R. S. Rao et al., "The human mutator gene homolog $\mathrm{MSH} 2$ and its association with hereditary nonpolyposis colon cancer," Cell, vol. 75, no. 5, pp. 1027-1038, 1993.

[140] Y. Wani, K. Notohara, C. Tsukayama, and S. Okada, "Reduced expression of hMLH1 and hMSH2 gene products in high-grade hepatocellular carcinoma," Acta Medica Okayama, vol. 55, no. 2, pp. 65-71, 2001.

[141] S. Matsukura, K. Miyazaki, H. Yakushiji, A. Ogawa, Y. Chen, and M. Sekiguchi, "Combined loss of expression of O6methylguanine-DNA methyltransferase and hMLH1 accelerates progression of hepatocellular carcinoma," Journal of Surgical Oncology, vol. 82, no. 3, pp. 194-200, 2003.
[142] S. Matsukura, H. Soejima, T. Nakagawachi et al., "CpG methylation of MGMT and hMLH1 promoter in hepatocellular carcinoma associated with hepatitis viral infection," British Journal of Cancer, vol. 88, no. 4, pp. 521-529, 2003.

[143] M. R. Hussein, "Alterations of p53, Bcl-2, and hMSH2 protein expression in the cirrhotic, macroregenerative, dysplastic nodules and hepatocellular carcinomas in Upper Egypt," Liver International, vol. 24, no. 6, pp. 552-560, 2004.

[144] T. Iwakuma, K. Sakumi, Y. Nakatsuru et al., "High incidence of nitrosamine-induced tumorigenesis in mice lacking DNA repair methyltransferase," Carcinogenesis, vol. 18, no. 8, pp. 16311635, 1997.

[145] A. Bhargava, G. V. Raghuram, N. Pathak et al., "Occult hepatitis $\mathrm{C}$ virus elicits mitochondrial oxidative stress in lymphocytes and triggers PI3-kinase-mediated DNA damage response," Free Radical Biology and Medicine, vol. 51, no. 9, pp. 1806-1814, 2011.

[146] Y. J. Wang, X. G. Chen, Z. Y. Xiao, G. T. Liu, and H. Sun, "Induction of cell cycle arrest by GL331 via triggering an ATMdependent DNA damage response in HepG2 cells," Journal of Asian Natural Products Research, vol. 14, no. 7, pp. 657-664, 2012.

[147] H. Wang, B. Zuo, H. Wang et al., "CGK733 enhances multinucleated cell formation and cytotoxicity induced by taxol in Chk1-deficient HBV-positive hepatocellular carcinoma cells," Biochemical and Biophysical Research Communications, vol. 422, no. 1, pp. 103-108, 2012.

[148] S. Fujimaki, Y. Matsuda, T. Wakai et al., "Blockade of ataxia telangiectasia mutated sensitizes hepatoma cell lines to sorafenib by interfering with Akt signaling," Cancer Letters, vol. 319, no. 1, pp. 98-108, 2012.

[149] W. Hanel and U. M. Moll, "Links between mutant p53 and genomic instability," Journal of Cellular Biochemistry, vol. 113, no. 2, pp. 433-439, 2012.

[150] K.-R. You, J. Wen, S.-T. Lee, and D.-G. Kim, "Cytochrome c oxidase subunit III: a molecular marker for N-(4hydroxyphenyl)retinamide-induced oxidative stress in hepatoma cells," Journal of Biological Chemistry, vol. 277, no. 6, pp. 3870-3877, 2002.

[151] L. T. Ng, L.-C. Chiang, Y.-T. Lin, and C.-C. Lin, "Antiproliferative and apoptotic effects of tetrandrine on different human hepatoma cell lines," The American Journal of Chinese Medicine, vol. 34, no. 1, pp. 125-135, 2006.

[152] M. F. Langelier and J. M. Pascal, "PARP-1 mechanism for coupling DNA damage detection to poly(ADP-ribose) synthesis," Current Opinion in Structural Biology, vol. 23, no. 1, pp. 134-143, 2013.

[153] V. Schreiber, F. Dantzer, J.-C. Amé, and G. De Murcia, "Poly(ADP-ribose): novel functions for an old molecule," Nature Reviews Molecular Cell Biology, vol. 7, no. 7, pp. 517-528, 2006.

[154] K. L. Lockett, M. C. Hall, J. Xu et al., “The ADPRT V762A genetic variant contributes to prostate cancer susceptibility and deficient enzyme function," Cancer Research, vol. 64, no. 17, pp. 6344-6348, 2004.

[155] F. Ye, Q. Cheng, Y. Hu, J. Zhang, and H. Chen, "PARP-1 Val762Ala polymorphism is associated with risk of cervical carcinoma," PLoS ONE, vol. 7, no. 5, Article ID e37446, 2012.

[156] H.-L. Ko and E.-C. Ren, "Novel poly (ADP-ribose) polymerase 1 binding motif in hepatitis B virus core promoter impairs DNA damage repair," Hepatology, vol. 54, no. 4, pp. 1190-1198, 2011.

[157] S. Sherlock, "Viruses and hepatocellular carcinoma," Gut, vol. 35 , no. 6, pp. 828-832, 1994. 
[158] N. Fujita, R. Sugimoto, N. Ma et al., "Comparison of hepatic oxidative DNA damage in patients with chronic hepatitis B and C," Journal of Viral Hepatitis, vol. 15, no. 7, pp. 498-507, 2008.

[159] T. Takayama, M. Makuuchi, S. Hirohashi et al., "Malignant transformation of adenomatous hyperplasia to hepatocellular carcinoma," The Lancet, vol. 336, no. 8724, pp. 1150-1153, 1990.

[160] M. Feitelson, "Hepatitis B virus infection and primary hepatocellular carcinoma," Clinical Microbiology Reviews, vol. 5, no. 3, pp. 275-301, 1992.

[161] S. A. Becker, T.-H. Lee, J. S. Butel, and B. L. Slagle, "Hepatitis B virus X protein interferes with cellular DNA repair," Journal of Virology, vol. 72, no. 1, pp. 266-272, 1998.

[162] R. P. Beasley, "Hepatitis B virus. The major etiology of hepatocellular carcinoma," Cancer, vol. 61, no. 10, pp. 1942-1956, 1988.

[163] R. P. Beasley, L. Y. Hwang, C. C. Lin, and C. S. Chien, "Hepatocellular carcinoma and hepatitis B virus," The Lancet, vol. 2, no. 8256, pp. 1129-1132, 1981.

[164] D. A. Shafritz, D. Shouval, and H. I. Sherman, "Integration of hepatitis B virus DNA into the genome of liver cells in chronic liver disease and hepatocellular carcinoma. Studies in percutaneous liver biopsies and post-mortem tissue specimens," The New England Journal of Medicine, vol. 305, no. 18, pp. 10671073, 1981.

[165] H. Tu, C. Bonura, C. Giannini et al., "Biological impact of natural $\mathrm{COOH}$-terminal deletions of hepatitis $\mathrm{B}$ virus $\mathrm{X}$ protein in hepatocellular carcinoma tissues," Cancer Research, vol. 61, no. 21, pp. 7803-7810, 2001.

[166] Y. Murakami, K. Saigo, H. Takashima et al., "Large scaled analysis of hepatitis B virus (HBV) DNA integration in HBV related hepatocellular carcinomas," Gut, vol. 54, no. 8, pp. 11621168, 2005.

[167] M. Kim, H. C. Lee, O. Tsedensodnom et al., "Functional interaction between Wnt3 and Frizzled-7 leads to activation of the Wnt/ $\beta$-catenin signaling pathway in hepatocellular carcinoma cells," Journal of Hepatology, vol. 48, no. 5, pp. 780-791, 2008.

[168] S. Wieland, R. Thimme, R. H. Purcell, and F. V. Chisari, "Genomic analysis of the host response to hepatitis B virus infection," Proceedings of the National Academy of Sciences of the United States of America, vol. 101, no. 17, pp. 6669-6674, 2004.

[169] S. Gordon, "Alternative activation of macrophages," Nature Reviews Immunology, vol. 3, no. 1, pp. 23-35, 2003.

[170] P. R. Taylor, L. Martinez-Pomares, M. Stacey, H. H. Lin, G. D. Brown, and S. Gordon, "Macrophage receptors and immune recognition," Annual Review of Immunology, vol. 23, pp. 901944, 2005.

[171] G. Kolios, V. Valatas, and E. Kouroumalis, "Role of Kupffer cells in the pathogenesis of liver disease," World Journal of Gastroenterology, vol. 12, no. 46, pp. 7413-7420, 2006.

[172] V. A. Bohr and G. L. Dianov, "Oxidative DNA damage processing in nuclear and mitochondrial DNA," Biochimie, vol. 81, no. 1-2, pp. 155-160, 1999.

[173] R. N. Aravalli, C. J. Steer, and E. N. K. Cressman, "Molecular mechanisms of hepatocellular carcinoma," Hepatology, vol. 48, no. 6, pp. 2047-2063, 2008.

[174] C.-M. Kim, K. Koike, I. Saito, T. Miyamura, and G. Jay, "HBx gene of hepatitis B virus induces liver cancer in transgenic mice," Nature, vol. 351, no. 6324, pp. 317-320, 1991.

[175] O. Billet, G. Grimber, M. Levrero, K. A. Seye, P. Briand, and V. Joulin, "In vivo activity of the hepatitis B virus core promoter: tissue specificity and temporal regulation," Journal of Virology, vol. 69, no. 9, pp. 5912-5916, 1995.
[176] T. A. Dragani, G. Manenti, H. Farza, G. Della Porta, P. Tiollais, and C. Pourcel, "Transgenic mice containing hepatitis B virus sequences are more susceptible to carcinogen-induced hepatocarcinogenesis," Carcinogenesis, vol. 11, no. 6, pp. 953-956, 1990.

[177] T.-H. Lee, M. J. Finegold, R.-F. Shen, J. L. DeMayo, S. L. C. Woo, and J. S. Butel, "Hepatitis B virus transactivator X protein is not tumorigenic in transgenic mice," Journal of Virology, vol. 64, no. 12, pp. 5939-5947, 1990.

[178] B. L. Slagle, T. H. Lee, D. Medina, M. J. Finegold, and J. S. Butel, "Increased sensitivity to the hepatocarcinogen diethylnitrosamine in transgenic mice carrying the hepatitis $\mathrm{B}$ virus $\mathrm{X}$ gene," Molecular Carcinogenesis, vol. 15, no. 4, pp. 261-269, 1996.

[179] O. Terradillos, O. Billet, C.-A. Renard et al., "The hepatitis B virus $\mathrm{X}$ gene potentiates $\mathrm{c}$-myc-induced liver oncogenesis in transgenic mice," Oncogene, vol. 14, no. 4, pp. 395-404, 1997.

[180] M. Dandri, P. Schirmacher, and C. E. Rogler, "Woodchuck hepatitis virus $\mathrm{X}$ protein is present in chronically infected woodchuck liver and woodchuck hepatocellular carcinomas which are permissive for viral replication," Journal of Virology, vol. 70, no. 8, pp. 5246-5254, 1996.

[181] P. Schirmacher, C. E. Rogler, and H. P. Dienes, "Current pathogenetic and molecular concepts in viral liver carcinogenesis," Virchows Archiv B: Cell Pathology Including Molecular Pathology, vol. 63, no. 2, pp. 71-89, 1993.

[182] M. A. Feitelson, M. Zhu, L.-X. Duan, and W. T. London, "Hepatitis B $\mathrm{x}$ antigen and p53 are associated in vitro and in liver tissues from patients with primary hepatocellular carcinoma," Oncogene, vol. 8, no. 5, pp. 1109-1117, 1993.

[183] X. W. Wang, K. Forrester, H. Yeh, M. A. Feitelson, J.-R. Gu, and C. C. Harris, "Hepatitis B virus X protein inhibits p53 sequencespecific DNA binding, transcriptional activity, and association with transcription factor ERCC3," Proceedings of the National Academy of Sciences of the United States of America, vol. 91, no. 6, pp. 2230-2234, 1994.

[184] S. Prost, J. M. Ford, C. Taylor, J. Doig, and D. J. Harrison, "Hepatitis B x protein inhibits p53-dependent DNA repair in primary mouse hepatocytes," Journal of Biological Chemistry, vol. 273, no. 50, pp. 33327-33332, 1998.

[185] R. Truant, J. Antunovic, J. Greenblatt, C. Prives, and J. A. Cromlish, "Direct interaction of the hepatitis B virus $\mathrm{HBx}$ protein with p53 leads to inhibition by $\mathrm{HBx}$ of p53 response element-directed transactivation," Journal of Virology, vol. 69, no. 3, pp. 1851-1859, 1995.

[186] Y. Matsuda, T. Wakai, M. Kubota et al., "DNA damage sensor gamma-H2AX is increased in preneoplastic lesions of hepatocellular carcinoma," The Scientific World Journal, vol. 2013, Article ID 597095, 7 pages, 2013.

[187] C. E. Canman, D.-S. Lim, K. A. Cimprich et al., "Activation of the ATM kinase by ionizing radiation and phosphorylation of p53," Science, vol. 281, no. 5383, pp. 1677-1679, 1998.

[188] M. B. Kastan and D.-S. Lim, “The many substrates and functions of ATM," Nature Reviews Molecular Cell Biology, vol. 1, no. 3, pp. 179-186, 2000.

[189] W.-H. Wang, R. L. Hullinger, and O. M. Andrisani, "Hepatitis B virus $\mathrm{X}$ protein via the $\mathrm{p} 38 \mathrm{MAPK}$ pathway induces $\mathrm{E} 2 \mathrm{~F} 1$ release and ATR kinase activation mediating p53 apoptosis," Journal of Biological Chemistry, vol. 283, no. 37, pp. 25455-25467, 2008.

[190] X.-Y. Wu, J.-J. Qian, Y. Lin, and M.-H. Zheng, "Hepatitis B virus $\mathrm{X}$ protein disrupts DNA interstrand crosslinking agent mitomycin C induced ATR dependent intra-S-phase checkpoint," European Journal of Cancer, vol. 44, no. 11, pp. 1596-1602, 2008. 
[191] K. Yamazaki, Y. Masugi, and M. Sakamoto, "Molecular pathogenesis of hepatocellular carcinoma: altering transforming growth factor- $\beta$ signaling in hepatocarcinogenesis," Digestive Diseases, vol. 29, no. 3, pp. 284-288, 2011.

[192] T. Severi, C. Ying, J. R. Vermeesch et al., "Hepatitis B virus replication causes oxidative stress in HepAD38 liver cells," Molecular and Cellular Biochemistry, vol. 290, no. 1-2, pp. 7985, 2006.

[193] N. Li, S. I. Grivennikov, and M. Karin, "The unholy trinity: inflammation, cytokines, and STAT3 shape the cancer microenvironment," Cancer Cell, vol. 19, no. 4, pp. 429-431, 2011.

[194] V. W.-S. Wong, J. Yu, A. S.-L. Cheng et al., "High serum interleukin-6 level predicts future hepatocellular carcinoma development in patients with chronic hepatitis B," International Journal of Cancer, vol. 124, no. 12, pp. 2766-2770, 2009.

[195] A. Arzumanyan, V. Sambandam, M. M. Clayton et al., "Hedgehog signaling blockade delays hepatocarcinogenesis induced by hepatitis B virus X protein," Cancer Research, vol. 72, no. 22, pp. 5912-5920, 2012.

[196] C. Ferri, F. Caracciolo, A. L. Zignego et al., "Hepatitis C virus infection in patients with non-Hodgkin's lymphoma," British Journal of Haematology, vol. 88, no. 2, pp. 392-394, 1994.

[197] I. Saito, T. Miyamura, A. Ohbayashi et al., "Hepatitis C virus infection is associated with the development of hepatocellular carcinoma," Proceedings of the National Academy of Sciences of the United States of America, vol. 87, no. 17, pp. 6547-6549, 1990.

[198] K. Machida, K. T.-N. Cheng, V. M.-H. Sung et al., "Hepatitis $\mathrm{C}$ virus induces a mutator phenotype: enhanced mutations of immunoglobulin and protooncogenes," Proceedings of the National Academy of Sciences of the United States of America, vol. 101, no. 12, pp. 4262-4267, 2004.

[199] K. Machida, K. T.-H. Cheng, V. M.-H. Sung, K. J. Lee, A. M. Levine, and M. M. C. Lai, "Hepatitis $\mathrm{C}$ virus infection activates the immunologic (type II) isoform of nitric oxide synthase and thereby enhances DNA damage and mutations of cellular genes," Journal of Virology, vol. 78, no. 16, pp. 8835-8843, 2004.

[200] M. M. C. Lai, "Hepatitis C virus proteins: direct link to hepatic oxidative stress, steatosis, carcinogenesis and more," Gastroenterology, vol. 122, no. 2, pp. 568-571, 2002.

[201] H. Ohshima and H. Bartsch, "Chronic infections and inflammatory processes as cancer risk factors: possible role of nitric oxide in carcinogenesis," Mutation Research: Fundamental and Molecular Mechanisms of Mutagenesis, vol. 305, no. 2, pp. 253264, 1994.

[202] M. Okuda, K. Li, M. R. Beard et al., "Mitochondrial injury, oxidative stress, and antioxidant gene expression are induced by hepatitis C virus core protein," Gastroenterology, vol. 122, no. 2, pp. 366-375, 2002.

[203] A. Maki, H. Kono, M. Gupta et al., "Predictive power of biomarkers of oxidative stress and inflammation in patients with hepatitis C virus-associated hepatocellular carcinoma," Annals of Surgical Oncology, vol. 14, no. 3, pp. 1182-1190, 2007.

[204] S. Mihm, A. Fayyazi, and G. Ramadori, "Hepatic expression of inducible nitric oxide synthase transcripts in chronic hepatitis $\mathrm{C}$ virus infection: relation to hepatic viral load and liver injury," Hepatology, vol. 26, no. 2, pp. 451-458, 1997.

[205] M. A. Rahman, D. K. Dhar, E. Yamaguchi et al., "Coexpression of inducible nitric oxide synthase and COX-2 in hepatocellular carcinoma and surrounding liver: possible involvement of COX-2 in the angiogenesis of hepatitis C virus-positive cases," Clinical Cancer Research, vol. 7, no. 5, pp. 1325-1332, 2001.
[206] S. Schweyer, S. Mihm, H. J. Radzun, H. Hartmann, and A. Fayyazi, "Liver infiltrating t lymphocytes express interferon $\gamma$ and inducible nitric Oxide synthase in chronic hepatitis $\mathrm{C}$ virus infection," Gut, vol. 46, no. 2, pp. 255-259, 2000.

[207] F. Izzo, M. Montella, A. P. Orlando et al., "Pegylated arginine deiminase lowers hepatitis $C$ viral titers and inhibits nitric oxide synthesis," Journal of Gastroenterology and Hepatology, vol. 22, no. 1, pp. 86-91, 2007.

[208] R. Parasole, F. Izzo, F. Perrone et al., "Prognostic value of serum biological markers in patients with hepatocellular carcinoma," Clinical Cancer Research, vol. 7, no. 11, pp. 3504-3509, 2001.

[209] F. Izzo, F. Cremona, P. Delrio et al., "Soluble interleukin-2 receptor levels in hepatocellular cancer: a more sensitive marker than alfa fetoprotein," Annals of Surgical Oncology, vol. 6, no. 2, pp. 178-185, 1999.

[210] S.-H. Choi and S. B. Hwang, "Modulation of the transforming growth factor- $\beta$ signal transduction pathway by hepatitis $\mathrm{C}$ virus nonstructural 5A protein," Journal of Biological Chemistry, vol. 281, no. 11, pp. 7468-7478, 2006.

[211] Q. L. Choo, K. H. Richman, J. H. Han et al., "Genetic organization and diversity of the hepatitis $\mathrm{C}$ virus," Proceedings of the National Academy of Sciences of the United States of America, vol. 88, no. 6, pp. 2451-2455, 1991.

[212] M. Hijikata, N. Kato, Y. Ootsuyama, M. Nakagawa, and K. Shimotohno, "Gene mapping of the putative structural region of the hepatitis $\mathrm{C}$ virus genome by in vitro processing analysis," Proceedings of the National Academy of Sciences of the United States of America, vol. 88, no. 13, pp. 5547-5551, 1991.

[213] A. Grakoui, C. Wychowski, C. Lin, S. M. Feinstone, and C. M. Rice, "Expression and identification of hepatitis $\mathrm{C}$ virus polyprotein cleavage products," Journal of Virology, vol. 67, no. 3, pp. 1385-1395, 1993.

[214] M. Hijikata, H. Mizushima, Y. Tanji et al., "Proteolytic processing and membrane association of putative nonstructural proteins of hepatitis C virus," Proceedings of the National Academy of Sciences of the United States of America, vol. 90, no. 22, pp. 10773-10777, 1993.

[215] Y. Ariumi, M. Kuroki, H. Dansako et al., "The DNA damage sensors ataxia-telangiectasia mutated kinase and checkpoint kinase 2 are required for hepatitis C virus RNA replication," Journal of Virology, vol. 82, no. 19, pp. 9639-9646, 2008.

[216] R. D. Kennedy and A. D. D'Andrea, "DNA repair pathways in clinical practice: lessons from pediatric cancer susceptibility syndromes," Journal of Clinical Oncology, vol. 24, no. 23, pp. 3799-3808, 2006.

[217] L. Chen, Y.-F. Yuan, Y. Li et al., "Clinical significance of CHD1L in hepatocellular carcinoma and therapeutic potentials of virusmediated CHD1L depletion," Gut, vol. 60, no. 4, pp. 534-543, 2011.

[218] S. Martin-Vilchez, E. Lara-Pezzi, M. Trapero-Marugán, R. Moreno-Otero, and P. Sanz-Cameno, "The molecular and pathophysiological implications of hepatitis B X antigen in chronic hepatitis B virus infection," Reviews in Medical Virology, vol. 21, no. 5, pp. 315-329, 2011.

[219] R. Wang, N. Zhao, S. Li et al., "MicroRNA-195 suppresses angiogenesis and metastasis of hepatocellular carcinoma by inhibiting the expression of VEGF, VAV2 and CDC42," Hepatology, vol. 58, no. 2, pp. 642-653, 2013.

[220] R. Lencioni, "Chemoembolization for hepatocellular carcinoma," Seminars in Oncology, vol. 39, no. 4, pp. 503-509, 2012.

[221] L. Liu, Z.-G. Ren, Y. Shen et al., "Influence of hepatic artery occlusion on tumor growth and metastatic potential in a 
human orthotopic hepatoma nude mouse model: relevance of epithelial-mesenchymal transition," Cancer Science, vol. 101, no. 1, pp. 120-128, 2010.

[222] J. Zhang, S. J. Lan, Q. R. Liu, J. M. Liu, and X. Q. Chen, "Neuroglobin, a Novel Intracellular Hexa-Coordinated Globin, Functions as a Tumor Suppressor in Hepatocellular Carcinoma via Raf/MAPK/Erk," Molecular Pharmacology, vol. 83, no. 5, pp. 1109-1119, 2013.

[223] Q. Zhang, X. Bai, W. Chen et al., "Wnt/beta-catenin signaling enhances hypoxia-induced epithelial-mesenchymal transition in hepatocellular carcinoma via crosstalk with hif-lalpha signaling," Carcinogenesis, vol. 34, no. 5, pp. 962-973, 2013.

[224] P. A. Farazi and R. A. DePinho, "Hepatocellular carcinoma pathogenesis: from genes to environment," Nature Reviews Cancer, vol. 6, no. 9, pp. 674-687, 2006.

[225] Y. Matsuda, T. Ichida, and M. Fukumoto, "Hepatocellular carcinoma and liver transplantation: clinical perspective on molecular targeted strategies," Medical Molecular Morphology, vol. 44, no. 3, pp. 117-124, 2011.

[226] C. Della Corte and M. Colombo, "Surveillance for hepatocellular carcinoma," Seminars in Oncology, vol. 39, no. 4, pp. 384-398, 2012.

[227] J. M. Llovet, S. Ricci, V. Mazzaferro et al., "Sorafenib in advanced hepatocellular carcinoma," The New England Journal of Medicine, vol. 359, no. 4, pp. 378-390, 2008.

[228] Á. M. Prendergast, S. Cruet-Hennequart, G. Shaw, F. P. Barry, and M. P. Carty, "Activation of DNA damage response pathways in human mesenchymal stem cells exposed to cisplatin or $\gamma$ irradiation," Cell Cycle, vol. 10, no. 21, pp. 3768-3777, 2011.

[229] D. Hanahan and R. A. Weinberg, "Hallmarks of cancer: the next generation,” Cell, vol. 144, no. 5, pp. 646-674, 2011.

[230] C.-H. Kim, S.-J. Park, and S.-H. Lee, "A targeted inhibition of DNA-dependent protein kinase sensitizes breast cancer cells following ionizing radiation," Journal of Pharmacology and Experimental Therapeutics, vol. 303, no. 2, pp. 753-759, 2002.

[231] X. Guo, Y. Ba, X. Ma et al., "A meta-analysis of array-CGH studies implicates antiviral immunity pathways in the development of hepatocellular Carcinoma," PLoS ONE, vol. 6, no. 12, Article ID e28404, 2011.

[232] Y.-J. Chen, C.-P. Lin, M.-L. Hsu, H.-R. Shieh, N. K. Chao, and K. S. C. Chao, "Sonic Hedgehog signaling protects human hepatocellular carcinoma cells against ionizing radiation in an autocrine manner," International Journal of Radiation Oncology Biology Physics, vol. 80, no. 3, pp. 851-859, 2011.

[233] S. Chae, Y. B. Kim, J.-S. Lee, and H. Cho, "Resistance to paclitaxel in hepatoma cells is related to static JNK activation and prohibition into entry of mitosis," The American Journal of Physiology: Gastrointestinal and Liver Physiology, vol. 302, no. 9, pp. G1016-G1024, 2012.

[234] H. Chen, C. Shao, H. Shi, Y. Mu, K. Sai, and Z. Chen, "Single nucleotide polymorphisms and expression of ERCC1 and ERCC2 vis-à-vis chemotherapy drug cytotoxicity in human glioma," Journal of Neuro-Oncology, vol. 82, no. 3, pp. 257-262, 2007.

[235] K. R. M. Martha, G. Rosangkima, L. Amenla, T. Rongpi, and S. B. Prasad, "Cisplatin- and dietary ascorbic acid-mediated changes in the mitochondria of Dalton's lymphoma-bearing mice," Fundamental and Clinical Pharmacology, vol. 27, no. 3, pp. 329-338, 2013.

[236] S. Ueda, K. Shirabe, K. Morita et al., "Evaluation of ERCC1 expression for cisplatin sensitivity in human hepatocellular carcinoma," Annals of Surgical Oncology, vol. 18, no. 4, pp. 12041211, 2011.

[237] S. Kuroda, Y. Urata, and T. Fujiwara, "Ataxia-telangiectasia mutated and the Mrell-Rad50-NBS1 complex: promising targets for radiosensitization," Acta Medica Okayama, vol. 66, no. 2, pp. 83-92, 2012.

[238] S. G. Lee and H. M. Rho, "Transcriptional repression of the human p53 gene by hepatitis B viral X protein," Oncogene, vol. 19, no. 3, pp. 468-471, 2000.

[239] I. Qadri, J. W. Conaway, R. C. Conaway, J. Schaack, and A. Siddiqui, "Hepatitis B virus transactivator protein, $\mathrm{HBx}$, associates with the components of TFIIH and stimulates the DNA helicase activity of TFIIH," Proceedings of the National Academy of Sciences of the United States of America, vol. 93, no. 20, pp. 10578-10583, 1996.

[240] M. Wang, C. Qin, J. Zhu et al., "Genetic variants of XRCC1, APE1, and ADPRT genes and risk of bladder cancer," DNA and Cell Biology, vol. 29, no. 6, pp. 303-311, 2010.

[241] P. Dong, M. Karaayvaz, N. Jia et al., "Mutant p53 gain-offunction induces epithelial-mesenchymal transition through modulation of the miR-130b-ZEB1 axis," Oncogene, vol. 32, no. 27, pp. 3286-3295, 2013.

[242] C. Gobert, A. Skladanowski, and A. K. Larsen, “The interaction between p53 and DNA topoisomerase I is regulated differently in cells with wild-type and mutant p53," Proceedings of the National Academy of Sciences of the United States of America, vol. 96, no. 18, pp. 10355-10360, 1999.

[243] X. Zhang, X. Miao, G. Liang et al., "Polymorphisms in DNA base excision repair genes ADPRT and XRCCl and risk of lung cancer," Cancer Research, vol. 65, no. 3, pp. 722-726, 2005.

[244] D. Delia, M. Paine, G. Buscemi et al., "MRE11 mutations and impaired ATM-dependent responses in an Italian family with ataxia-telangiectasia-like disorder," Human Molecular Genetics, vol. 13, no. 18, pp. 2155-2163, 2004.

[245] M. Gatei, B. Jakob, P. Chen et al., "ATM protein-dependent phosphorylation of Rad50 protein Regulates DNA repair and cell cycle control," Journal of Biological Chemistry, vol. 286, no. 36, pp. 31542-31556, 2011.

[246] J. He, L. Z. Shi, L. N. Truong et al., "Rad50 zinc hook is important for the Mrell complex to bind chromosomal DNA doublestranded breaks and initiate various DNA damage responses," The Journal of Biological Chemistry, vol. 287, no. 38, pp. 3174731756, 2012.

[247] J. Steffen, D. Nowakowska, A. Niwińska et al., "Germline mutations $657 \mathrm{del} 5$ of the NBS1 gene contribute significantly to the incidence of breast cancer in Central Poland," International Journal of Cancer, vol. 119, no. 2, pp. 472-475, 2006.

[248] K. A. Zuhlke, A. M. Johnson, L. A. Okoth et al., "Identification of a novel NBN truncating mutation in a family with hereditary prostate cancer," Familial Cancer, vol. 11, no. 4, pp. 595-600, 2012.

[249] S. V. Kozlov, M. E. Graham, B. Jakob et al., "Autophosphorylation and ATM activation: additional sites add to the complexity," Journal of Biological Chemistry, vol. 286, no. 11, pp. 9107-9119, 2011.

[250] S. V. Kozlov, M. E. Graham, C. Peng, P. Chen, P. J. Robinson, and M. F. Lavin, "Involvement of novel autophosphorylation sites in ATM activation," EMBO Journal, vol. 25, no. 15, pp. 3504-3514, 2006.

[251] C. J. Bakkenist and M. B. Kastan, "DNA damage activates ATM through intermolecular autophosphorylation and dimer dissociation," Nature, vol. 421, no. 6922, pp. 499-506, 2003. 
[252] I. Rappold, K. Iwabuchi, T. Date, and J. Chen, “Tumor suppressor p53 binding protein 1 (53BP1) is involved in DNA damagesignaling pathways," Journal of Cell Biology, vol. 152, no. 3, pp. 613-620, 2001.

[253] Å. Mattsson, S. Lundstedt, and U. Stenius, "Exposure of HepG2 cells to low levels of PAH-containing extracts from contaminated soils results in unpredictable genotoxic stress responses," Environmental and Molecular Mutagenesis, vol. 50, no. 4, pp. 337-348, 2009.

[254] X. Yang, P. Zou, J. Yao et al., "Proteomic dissection of cell typespecific $\mathrm{H} 2 \mathrm{AX}$-Interacting protein complex associated with hepatocellular Carcinoma," Journal of Proteome Research, vol. 9, no. 3, pp. 1402-1415, 2010.

[255] Z. Wang, J. Yan, H. Lin et al., “Toll-like receptor 4 activity protects against hepatocellular tumorigenesis and progression by regulating expression of DNA repair protein Ku70 in mice," Hepatology, vol. 57, no. 5, pp. 1869-1881, 2013.

[256] Z. Wang, H. Lin, F. Hua, and Z. W. Hu, "Repairing DNA damage by XRCC6/KU70 reverses TLR4-deficiency-worsened HCC development via restoring senescence and autophagic flux," Autophagy, vol. 9, no. 6, pp. 925-927, 2013.

[257] S. Wei, M. Xiong, D.-Q. Zhan et al., "Ku80 functions as a tumor suppressor in hepatocellular carcinoma by inducing s-phase arrest through a p53-dependent pathway," Carcinogenesis, vol. 33, no. 3, pp. 538-547, 2012.

[258] Z.-J. Yu, J.-G. Sui, Y.-Q. Ding, Z.-S. Cao, P.-K. Zhou, and D.C. Wu, "Expression of DNA-PK in hepato- and cholangioneoplasms and its significance," Chinese Journal of Hepatology, vol. 12, no. 11, pp. 652-655, 2004.

[259] G. Wu, L. Xu, N. Lin, and B. Liu, "UCN-01 induces S and G2/M cell cycle arrest through the p53/p21waf1 or CHK2/CDC25C pathways and can suppress invasion in human hepatoma cell lines," BMC Cancer, vol. 13, article 167, 2013. 


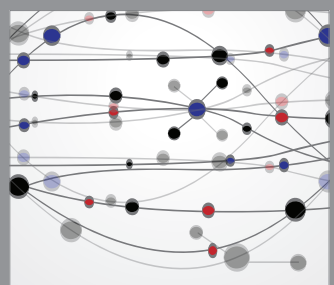

The Scientific World Journal
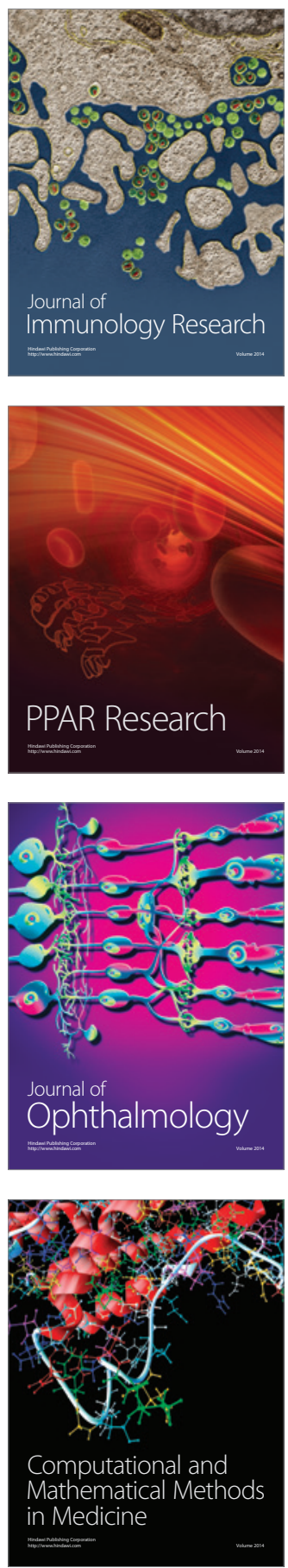

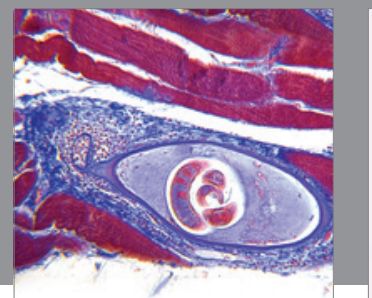

Gastroenterology

Research and Practice
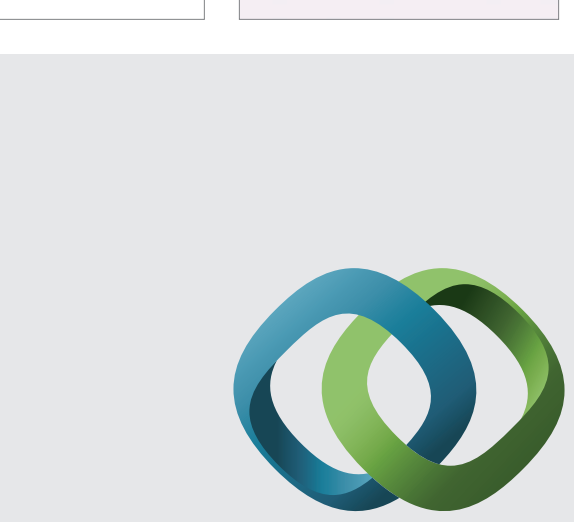

\section{Hindawi}

Submit your manuscripts at

http://www.hindawi.com
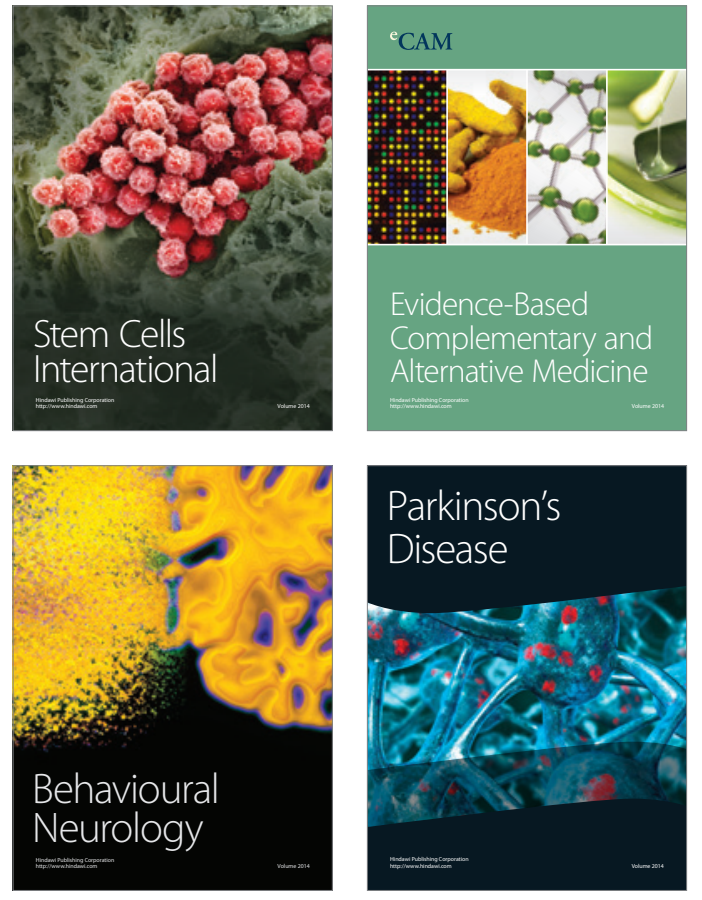
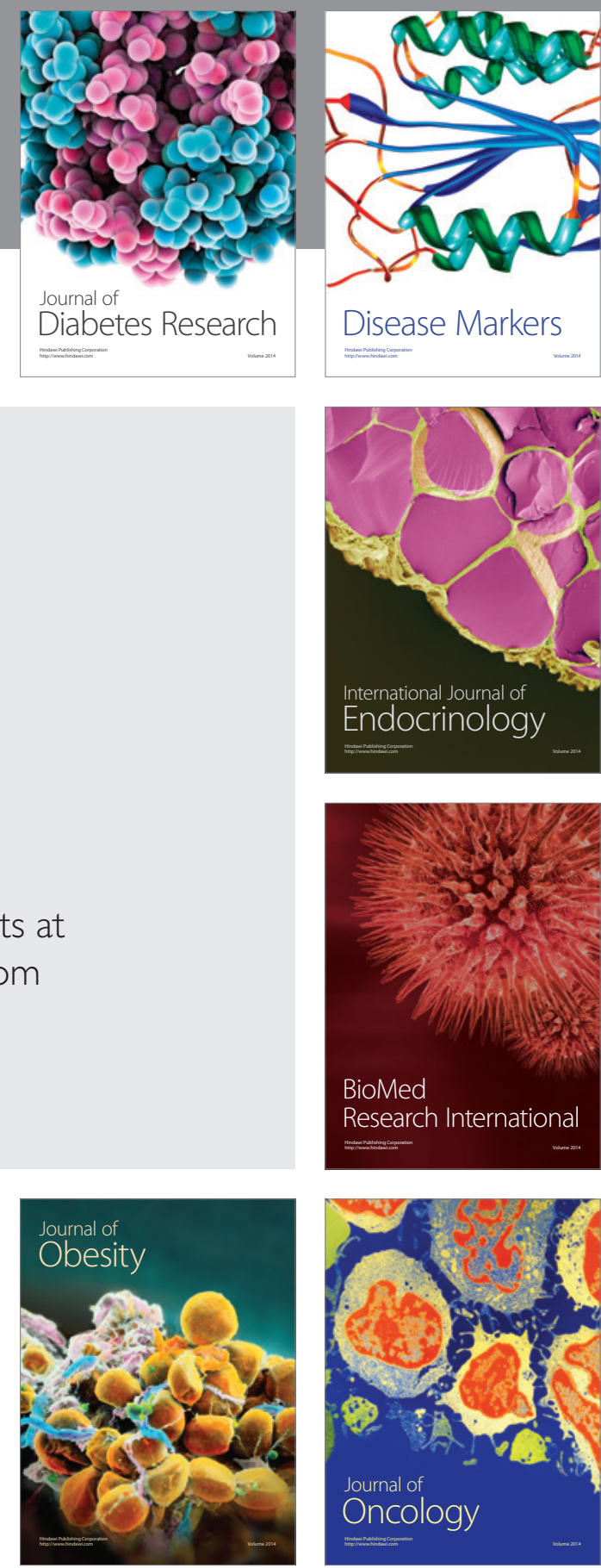

Disease Markers
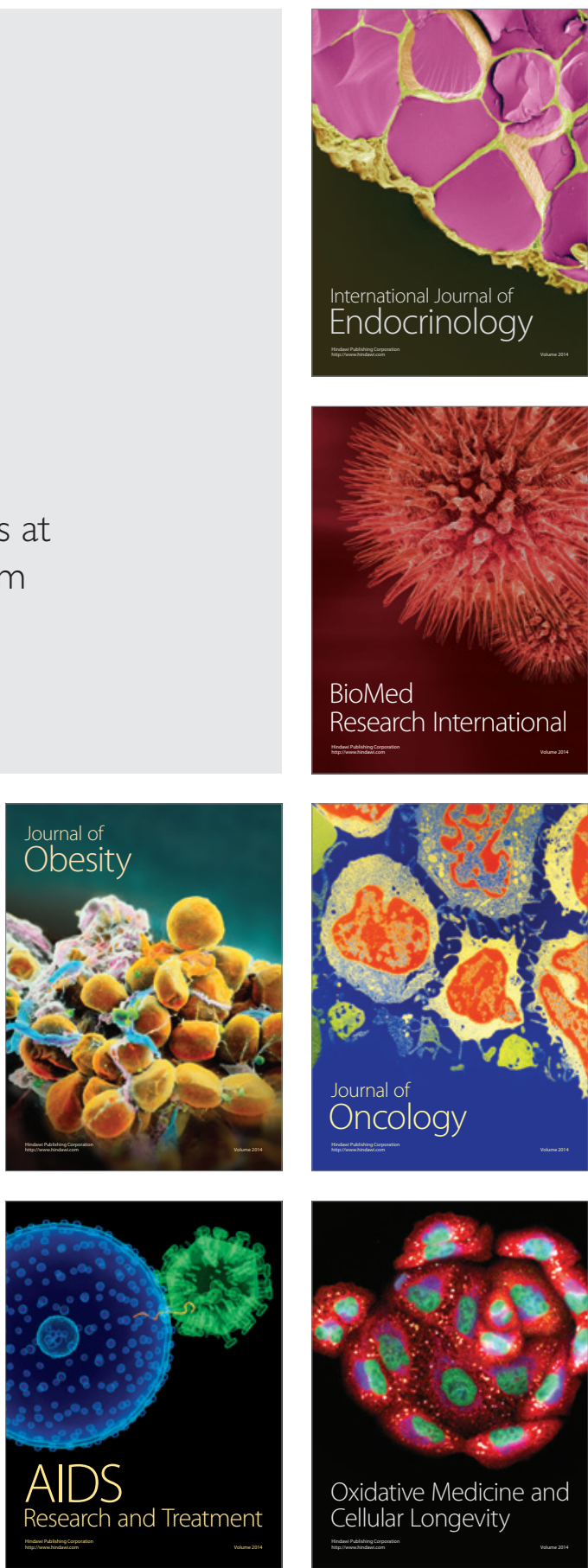